\title{
HOW DOES BUSINESS ANALYTICS CONTRIBUTE TO BUSINESS VALUE?
}

\begin{abstract}
This paper presents a model, synthesized from the literature, of factors that explain how business analytics contributes to business value. It also reports results from a preliminary assessment of that model. The model consists of two parts: a process and a variance model. The process model depicts the analyze-insight-decision-action process through which use of an organization's business-analytic capabilities is intended to create business value. The variance model proposes that the five factors in Davenport et al.'s (2010) DELTA model of business-analytics success factors, six

= - from Watson and Wixom (2007), and three from Seddon et al.'s (2010) model of organizational benefits from enterprise systems, assist a firm to gain business value from business analytics. A preliminary assessment of the model was conducted using data from 100 customer-success stories from vendors such as IBM, SAP, and Teradata. Our conclusion is that the business-analytics success model (BASM) is likely to be a useful basis for future research.
\end{abstract}

Keywords: business analytics, business value, business intelligence, organizational benefits, success model

This is the author manuscript accepted for publication and has undergone full peer review but has not been through the copyediting, typesetting, pagination and proofreading process, which may lead to differences between this version and the Version of Record. Please cite this article as doi: 10.1111/isj.12101 


\section{HOW DOES BUSINESS ANALYTICS CONTRIBUTE TO BUSINESS VALUE?}

\section{Introduction}

Although there are many definitions of both "business analytics" and "business intelligence", in this paper we define business analytics (BA) as the use of data to make sounder, more evidence-based business decisions ${ }^{1}$, and business intelligence (BI) as IT-based tools, e.g., data warehouses, on-line analytical processing (OLAP), statistical and quantitative tools, visualization tools, and data mining tools that enable BA (Howson, 2011; Negash, 2004; Ramamurthy et al. 2008). In the past decade, there has been massive interest worldwide in both BA and BI. As evidence, BI topped the list of "Technical priorities for CIOs" in Gartner's annual global surveys of CIOs in the three of the five years, 2007-2011 (Hagerty et al., 2012, p. 47). Further, the spate of multi-billion dollar takeovers of BI firms ${ }^{2}$, as well as various vendors' current advertising of their in-memory database technologies (IBM, 2015; SAP, 2014) suggests that IT vendors believe that BA is likely to make a major contribution to firm performance in the coming decade. Echoing this view, advisory-services firms such as McKinsey (McGuire, 2013) and the International Institute for Analytics (IIA) also argue that analytics promises to be a major source of competitive advantage in years to come. Finally, professional organizations such as INFORMS and TDWI now offer analytics certification. Clearly, BA in all its variantsincluding so-called "big data"-is a topic of great interest to the business community.

Organizations invest in BA in the pursuit of competitive advantage 3 , or if they are not-for-profit organizations, to help them find ways to achieve their goals more effectively or with fewer resources. To achieve these benefits, managers need to have a clear understanding of how an organization's BA capabilities actually influence organizational performance. However, the various models that we have been able to find in the literature are so different that it must be hard for managers to decide what they need to do to realize greater business value from BA. As evidence, in online Appendix 1 we have reproduced 16 models of factors affecting organizational benefits, or business value, from $\mathrm{BA}^{4}$. These models were identified using Google and Google Scholar to search for topics such as "business analytics", "business intelligence", "data warehousing", etc., then selecting documents that contained implicit or explicit models of factors affecting organizational benefits from BA. Models from three of

\footnotetext{
${ }^{1}$ Holsapple et al. (2014) list 18 different definitions of BA, and end with a definition similar to ours: "we adopt a general core characterization of business analytics as concerned with evidence-based problem recognition and solving that happen within the context of business situations".

2 e.g., of Hyperion by Oracle, of Cognos and SPSS by IBM, of BusinessObjects by SAP, and of Omniture by Adobe.

3 According to Peteraf and Barney (2003, p.314), "An enterprise has a Competitive Advantage if it is able to create more economic value than the marginal (breakeven) competitor in its product market".

${ }^{4}$ In this paper, we treat the two terms "organizational benefits" and "business value" as synonyms.
} 
the most highly cited studies have been reproduced in Figure 1. Figure 1A, from Wixom and Watson (2001) -an MIS Quarterly paper with 1138 Google-Scholar citations in November 2015-claims that the key to data warehousing success is to run successful implementation projects that result in high data and system quality. Figure 1B, our depiction of the DELTA model in Davenport et al. (2010) -a book with 252 Google-Scholar citations in November 2015-claims that the key to business value from BA is to achieve high scores on five factors: Data quality, Enterprise-wide integration, Leadership, well-chōsen Targets, and Analytic people. Figure 1C, from Clark et al. (2007) -an MIS Quarterly paper with 201 Google-Scholar citations in November 2015-shows 20 interrelated factors that influence Perceived Management Support System (MSS) Benefits. As one works one's way through model after model in Appendix 1, each introducing new factors and its own perspective on how BA contributes to organizational performance, it is hard to discern many underlying patterns that managers can build on to guide their own decision making. For example, Data Quality is mentioned in Figures 1A and 1B; aspects of leadership (Champion, Leadership, and Executive Commitment) are mentioned in Figures 1A, 1B, and 1C; implementation projects are highlighted in Figure 1A and mentioned in Figure 1C ("Development Effort"). Does this mean that Data Quality, Leadership, and Implementation projects are fundamental factors affecting business value from BA? If so, how are these factors inter-related? Moreover, few of the papers presenting the 16 different models reproduced in Appendix 1 cite the Psychology and Management literatures. Yet topics such as human problem solving, the nature of insight, and human decision making-which are important for understanding how BA contributes to organizational performance-have been studied for years in those literatures. Why have not more BA studies attempted to build on this well-researched literature?

After asking many questions such as these, we came to the conclusions that (a) Business Analytics is such a new and rapidly evolving research topic that there has been very little chance yet to develop any cumulative research tradition, and (b) it would be helpful if a literature-review-based summary or synthesis were undertaken to combine key insights from all these models and literatures. We therefore found ourselves asking the following two research questions:

1. How does business analytics contribute to business value?

2. What can managers do to realize greater organizational benefits from business analytics?

To answer both these questions we synthesized an integrated model from the various bodies of literature, then conducted a preliminary assessment of the explanatory power of the new model by examining the extent to which it corresponded to success stories about BA use that various BI vendors had published on their websites.

For structuring this paper, we decided follow Zmud's (1995) guidelines. Those guidelines say: (a) "With an empirical article, the theory section would typically follow the introduction and precede the 
discussion of the research methodology, analysis and results" (p.xxxviii), and (b) "the theory section should begin with an overview of the conceptual or research model being developed. Ideally, such an overview should be accompanied by a visual aid to ease the readers' comprehension of your ideas" (p.xxxix). We have followed these guidelines below. The development of our business analytics success model (BASM) is discussed in the first (and longer) part of this paper. Results of our preliminary assessment of the model are presented in the second part of the paper.

\section{Theory}

The Business-Analytics Success Model (BASM) that we synthesized from the literature is shown in Figure 2. This model was developed to include what we judged to be key insights from (a) the 16 models presented in online Appendix 1, particularly Davenport at al.'s (2010) DELTA model, which we judged to be the strongest model that we reviewed, (b) the broader IS literature, particularly the key insight from Seddon et al. (2010) that most of the increases in organizational benefits from enterprise systems (ES) may be attributed to ongoing major ES improvement projects, (c) the psychology literature on the nature of human decision making and the meaning of "insight", and (d) the management literature on how use of scarce BA resources might result in competitive advantage ${ }^{5}$. The result of this literature-based sense-making effort was the BASM. The BASM is intended to apply to any organization that uses BA in the pursuit of competitive advantage.

[Figure 2 goes here]

The BASM (Figure 2) consists of two mutually compatible views of how use of business analytics contributes to organizational performance: a process model (in Panel A) that answers research question 1, and a variance model (in Panel B) that answers research question 2. Constructs for these two views are defined in Tables 1 and 2, respectively. Webster and Watson (2002) explain the difference between process and variance theories (we take the term "theories" to include models) as follows: "Variance theories incorporate independent variables that cause variation in dependent variables. In contrast, process theories use events and states to help explain dynamic phenomena." (p.xix). Another helpful explanation comes from Langley who says that process research "explicitly incorporates temporal progressions of activities as elements of explanation and understanding" (Langley et al. 2013, p.1).

The two sub-models in Figure 2 thus provide two different-though mutually compatibleexplanations of how BA use in organizations leads to organizational benefits. The process in Panel A is executed over and over by different people and groups as they use analytic tools and make decisions in the focal organization. By contrast, Panel B assumes that Panel A's processes are in full flight in many parts of the organization, and compares levels of variables hypothesized to be causally related to

${ }^{5}$ A more detailed discussion of the method used for synthesizing the BASM is presented in Appendix 2. 
organizational benefits from BA use. Said differently, the integrated BI platform, high-quality data, and analytical people in the process model refer to the same physical things as those referenced in H1H3 in the variance model, yet the process model refers to the actual things, whereas the variance model compares attributes of those things, e.g., the quality of the analytical people in H3. Use of these two sub-models allows us to say more about how business analytics contributes to business value than is possible with either model alone.

The BASMis explained and justified in more detail in the next two major sections.

\section{The Process Model in the BASM (Panel A in Figure 2)}

The process model in the BASM (Panel A in Figure 2) presents a process- or temporally oriented explanation of how individual organizations use business analytics to create business value. It is intended to be consistent with the literature on problem solving (Newell and Simon 1972, Pretz et al. 2003), insight (Sternberg and Davidson 1996, Bowden et al. 2005), the resource-based view of the firm (Barney 1991, Barney et al. 2011), the dynamic-capabilities view of the firm (Teece et al. 1997), Beer's (1972, 1984) Viable System Model (VSM), and the IS literature on business analytics and business intelligence, particularly the work of Davenport and Harris (2007), Davenport et al. (2010), and Davenport and Kim (2013). In this process model it is argued that the prime drivers of business value from BA are actions driven by new insights and improved decision making. (By contrast, the prime drivers of business value from, say, investments in large-scale enterprise systems are greater integration and improved business processes (Davenport et al. 2004).)

The focal organization in the BASM process model may be an organization or any of its subunits, e.g., its divisions or departments. Within its environment, the focal organization uses its many resources to design, produce, and supply goods and/or services to its customers. By "resources" we mean "all assets, capabilities, organizational processes, firm attributes, information, knowledge, etc. controlled by a firm that enable the firm to conceive of and implement strategies that improve its efficiency and effectiveness" (Barney 1991, p.101). Use of these resources enables the firm to survive, and in some cases, thrive. However, as pointed out by Beer (1972), managing the use of an organization's resources requires huge amounts of information from both within and outside the organization. The BASM assumes that resources, including people, for analyzing this information are embedded in many places throughout the focal organization.

The left-hand side of Panel A relates to the use of business-analytic resources within the focal organization to produce information, insight, and decisions. The right-hand side relates to the use of that organization's entire set of resources to produce business value. The single-line arrows in Panel A mean "leads to" in the sense that A leads to, or must be completed before, B. The two block arrows labeled "enable" are intended to remind the reader that the organization must control resources in 
order to use them. It is these resources, owned or controlled by the organization, that are depicted on the lower left and lower right of Panel A of Figure 2.

[Table 1 goes here]

\section{The three paths in Panel A}

Within the process model in Panel A, three paths have been highlighted, numbered 1 to 3 . Each path is now discussed in turn. First, reading horizontally from left to right across the top of Panel A, Path 1 says that in a viable organization, Use of the organization's current Analytic Resources by people in many different parts of the organization produces Insights that lead to Decisions that lead (via the arrow labeled "Path 1") to Intendedly Value-Creating Actions (e.g., competitive actions) that lead to outcomes that senior managers in the organization would regard as beneficial, termed Organizational Benefits (e.g., profit). Path-1 usage leverages existing resources to produce value. The most common BI tools likely to be used in Path-1 are those identified in Howson's (2011) report, based on a survey of $460 \mathrm{BI}$ users, which says that the "most successful" (i.e., most used) BI modules were, in descending order: Business or Ad Hoc Query 62\%, Fixed reports 54\%, Dashboards 54\%, and OLAP 36\% (Howson 2011, p.12). These tools, which may have been purchased or specially developed by the organization to support groups of users, are the most likely sources of insight for end users (including executive end users) in the process model in Panel A. However, use of spreadsheets (Albright et al. 2010) and search engines are other examples of Path-1 usage. (Search engines allow users to search for information and patterns in the huge unstructured distributed database that is the World Wide Web.)

Second, reading horizontally again from left to right, Path 2 says that sometimes Use of an organization's current analytical resources by people in different parts of the organization produces Insights that lead to Decisions that lead (via the arrows labeled "Path 2") to Intendedly Value-Creating actions that change organizational resources. Assuming these changed resources enable the organization to operate or compete more effectively in future, this is a dynamic-capabilities view of how use of business analytics creates business value (Teece 2009).

Third, Path 3 on the left of Panel A is intended to recognize that Use of analytic resources may sometimes lead directly to changes in those analytic resources. Examples of such changes might include improved data quality as the result of data-cleansing efforts, or more capable analytical people, as a result of their learning how to use analytic tools more effectively, or organizational learning about how to use analytics effectively (Shanks and Bekmamedova 2012b). Our goal in this paper is to focus on the intendedly value-creating actions in Paths 1 and 2, so Path 3 is not discussed any further.

A good example to illustrate the meaning of Paths 1 and 2 in the process model in Panel A comes from Davenport and Harris (2007). According to those authors, some years ago the UK supermarket chain, 
Tesco, set up a Clubcard loyalty program that motivates customers to present their card with most purchases. Tesco now uses its analytic resources to analyze checkout data to understand the purchasing preferences of its customers. Based on those preferences, Tesco makes automated offers in its direct-marketing program. This program has apparently been so effective that at the time the book was written Tesco had a coupon redemption rate ten times the industry average:

"Tesco says that it issues 7 million targeted variations of product coupons a year, driving the coupon redemption rate, customer loyalty, and ultimately financial performance to market-leading heights." (Davenport and Harris 2007, pp.90-91)

The setting up of the loyalty program and the building of the systems and processes to analyze data correspond to Intendedly value-creating actions that change the organization's resources (see the lower right of Panel A in Figure 2). It is not clear from Davenport and Harris (2007) whether the decision to build these resources at Tesco was based on use of business analytics, but if it had been, it would have been an example of execution of Path 2, i.e., of use of analytics that resulted in a change in organizational resources. Once the new BA resources were built, Tesco's regular use of these resources to make offers in its direct-marketing program corresponds to Path 1 in Panel A in Figure 2, i.e., to Shanks and Bekmamedova's (2012) Operational BA use.

Extending the Tesco example further, non-routine analysis of the same checkout data by Tesco's data scientists (Davenport and Patil 2012) might lead Tesco to gain insights into patterns of purchases in inner city stores that lead it to create new organizational resources, e.g., to open a new chain of convenience stores that sells only a narrow range of products. Such actions would be another example of execution of Path 2 in Panel A of Figure 2. Subsequent operations of these stores (not necessarily involving use of BA) would then be the source of business value for Tesco flowing from the BA-driven decision to change organizational resources.

Our goal now is to convince the reader that (a) the three constructs Use Analytic Resources, Insight(s), and Decisions(s) on the left of the process model in Panel A of Figure 2 are each critical in the process that produces business value from BA, and (b) these three process steps are all intensely human activities.

\section{BA Use is Problem Solving}

Use Analytic Resources means usage of BI technology by people across the organization. This BA Usage is the fundamental driver of business value from BA. The reason is simple: no use, no benefits! The resources involved in BA usage are depicted in the box labeled Analytical Resources in the lower left of Panel A. The five dot points in this box, and their grouping under the headings Enabling Technology and Analytical People, are our attempt to summarize concepts discussed in chapters 8 and 7, respectively, of Davenport and Harris (2007). In those two chapters, Davenport and Harris 
(2007) argue that Enabling Technology and Analytical People are key resources that an organization must have to be able to create business value from BA. With respect to technology, Davenport and Harris (2007) use the term "BI architecture" to describe an organization's enabling technology:

"The business intelligence architecture (a subset of the overall IT architecture) is an umbrella term for an enterprise-wide set of systems, applications, and governance processes that enable sophisticated analytics, by allowing data, content, and analyses to flow to those who need it, when they need it." (Davenport and Harris 2007, p.155)

We now want to examine the Use Analytical Resources construct at the top left of Figure 2, and ask: 'What do human beings actually do when they use the enabling BI Technology?' Our answer is that what they do is intendedly rational problem solving (Simon 1955), and their goal is to produce insights from the available data. BA Usage is not often described as human problem solving ${ }^{6}$, but that, we argue, is what it is. Human problem solving is a hugely complex and much studied topic (Simon 1955, Newell and Simon 1972, Amabile 1983, Davidson and Sternberg 2003), but Pretz et al. (2003) explain that in simple terms it may be viewed as a cycle consisting of the seven steps shown in the Figure 37. Pretz et al. (2003) also explain that these steps are often not executed in the vertical step-1 to step-7 sequence shown (that is the reason for all the arrows on the left of the boxes in Figure 3).

[Figure 3 goes here]

Since it is hard to appreciate both the personal human effort and sometimes very creative thinking in the process depicted in Figure 3, we have decided to use the following trivial example of BA use to remind the reader of the difficult and very-human process of attempting to extract insight from even a tiny sample of data. With the goal of bringing the process depicted in Figure 3 to life, we ask the reader to please consider the data headed x1, x2, and y shown in columns A, B, and C of Figure 4. Looking only at columns A, B, and C, can you, the reader, see any relationship between the numbers in the columns?

[Figure 4 goes here]

Assuming that the reader has now spent a minute or so trying to identify the relationship between $\mathrm{x} 1$, $\mathrm{x} 2$, and $\mathrm{y}$ in columns $\mathrm{A}, \mathrm{B}$, and $\mathrm{C}$, we now offer the following comments. First, scanning down columns A, B, and C, one can see that when $\mathrm{x} 1$ and $\mathrm{x} 2$ (columns A and B) are high (e.g., in rows 8 and 11), $\mathrm{y}$ is high, and when $\mathrm{x} 1$ and $\mathrm{x} 2$ are low (e.g., row 16), $\mathrm{y}$ is low. But it is hard to see a clear pattern.

\footnotetext{
${ }^{6}$ For example, the term "problem solving" appears only once in Davenport and Harris (2007), thrice in Albright et al. (2010), and twice in Loshin (2012). However, this absence of reference to "problem solving" is remedied by Davenport and Kim (2013), who make is clear that-consistent with Figure 3-doing BA means: (a) problem framing, (b) problem solving, and (c) communicating the results.

We, the authors of this paper, prepared this diagram. It is not in Pretz et al. (2003). Amabile (1983, Fig 2, p.362) shows a similar process, though her diagram has only five steps.
} 
Second, since both the problem (finding the relationship between $\mathrm{x} 1, \mathrm{x} 2$, and $\mathrm{y}$ ) and representation (the data for these three variables are represented in columns A-C in Figure 4) in this example (step 2 in Figure 3) are clear, many of us would jump quickly to step 3 in Figure 3 and propose a solution strategy that involves using, say, a combination of scatterplots (data visualization) and OLS regression to explore the relationship. Third, knowing (step 4) that the spreadsheet program (Excel) can both draw graphs and do OLS regression, we might decide to allocate mental and physical resources (stêp 5) to solving the problem by (i) drawing various graphs (e.g., the scatterplot in the top right of Figure 4, which shows an underlying positive correlation between $\mathrm{x} 2$ and y), and (ii) clicking on "Data Analysis" at the top right of Figure 4 and producing the output shown in columns G to M of Figure 4. Fourth, using our knowledge of statistics (back to step 4), we might infer that $23 \%$ (cell H6) of the variance in column y may be explained by an equation of the form $y=6.90-0.16 * x 1+0.49 * x 2$ (cells H17-H19) (step 5). Fifth, to assess progress towards our goal (step 6) of explaining the relationship between $\mathrm{x} 1, \mathrm{x} 2$, and $\mathrm{y}$, we might compute the value estimated for $\mathrm{y}$ for each row (step 5). This is shown in column E. Sixth, Evaluating our solution for accuracy (step 7), i.e., comparing column $\mathrm{E}$ with $\mathrm{C}$, we might note that the value for our y-estimate is high(ish) for row 8 and low(ish) for row 16, which is comforting, but there is still much variance in $\mathrm{y}$ that is not explained by $\mathrm{x} 1$ and $\mathrm{x} 2$. Seventh, having achieved a clearer understanding of the problem (back to step 1) we might find ourselves asking what to do next. (At this point, we shall terminate the exercise.)

Our reason for including this example (Figures 2 and 3 and the paragraph above) in this paper is to make three very simple points: (1) despite all the computing power available to the analyst, the creative work (e.g., sense-making, framing, understanding, and deciding) in using business-analytics tools is done by people, not computers, (2) the work these people do is called "human problem solving", a much-studied topic of huge complexity, and (3) the model in Figure 3 provides a useful depiction of this intensely human problem-solving activity. In other words, it is people who look at the data, assign meaning to it, search for patterns, sense opportunities, and so on. Further, it is people-with all their different knowledge and cognitive capabilities and limitations-who derive insights, through a process like that depicted in Figure 3.

It is our contention that the problem-solving process depicted in Figure 3 must be executed over and over in organizations around the world as people in the organization seek to gain value from BA. This problem-solving activity is the first key and necessary step along the pathway from BA Use to Organizational Benefits from BA depicted in Panel A of Figure 2.

\section{Insight}

Having examined the box labeled Use Analytic Resources, and shown how much personal sensemaking effort is required from the people using BI tools, we now turn to the box labeled Insight(s) in 
Panel A of Figure 2. In this BA context, "Insights" are defined in Table 1 to mean "The gaining of a deep or deeper understanding of something, arising from use of business-analytic (BA) capabilities." Davenport and Patil (2012) describe insights as "treasure" coaxed "out of messy, unstructured data" (p.70). The goal of BA usage is to produce such insights. Again, it is important to point out that insights occur in people's heads, not in computers, and that they are-possibly erroneousinterpretations of reality (Daft and Weick 1984, Shah et al. 2012).

At this point, we would like to reveal to the reader that the spreadsheet formula used for computing the values in column $\mathrm{C}$ in Figure 4 was $\mathrm{y}=\operatorname{rand}() * 10+0.3^{*} \mathrm{x} 1+0.4 * \mathrm{x} 2$, where "rand () " generates a random number between 0 and 1 . Please consider for a moment how this formula led to the generation of the numbers in column C. For example, the number in cell $\mathrm{C} 2$ was computed as: $\mathrm{y}=0.774 * 10+0.3 * 4+0.4 * 10$ (where 0.774 is a random number between 0 and 1 that was generated automatically by Excel, $\mathrm{x} 1=4$ in cell $\mathrm{A} 2$, and $\mathrm{x} 2=10$ in cell $\mathrm{B} 2$ ). There is so much randomness in $\mathrm{y}$ due to the first term in the formula that for the data in Figure 4, the regression algorithm has struggled to identify the true underlying relationship ( $y=5+0.3^{*} \mathrm{x} 1+0.4^{*} \mathrm{x} 2$ ). Of course, in the real world, the analyst does not know the true relationship. He/ she has to make do with the OLS regressioncoefficient estimates such as those in cells H17-H19 of Figure 4. As is clear from this example, these estimates can be quite misleading ${ }^{8}$.

It is our hope that when the equation for column C was revealed, the reader suddenly "saw" the relationship between the columns more clearly. Such clarity of understanding is called "insight". According to the literature on insight (e.g., Dominowski and Dallob 1996, Gruber 1996, Mayer 1996, Schooler et al. 1996, Bowden et al. 2005), some insights are clearer, or likely to be more valuable, than others, and problem solvers often report a sudden "flash" of insight: "When the solution is seen, all the parts suddenly seem to fit together" (Schooler et al. 1996, p.579). Bowden et al. (2005) report that such "flashes" of insight correspond to measurable electrical activity in the brain. In addition, BA users are often aware of the value of their different insights. For example, in a study of the use of data-visualization BI tools such as Tibco's Spotfire (http://spotfire.tibco.com/), Saraiya et al. (2006, p.4) asked a group of bioinformaticians to rank insights on a scale from 1-5, with 5 being "the most significant". The tables that follow in their paper suggest that the analysts were able to do this quite easily (though we are not told how accurately).

Our goal in this paper to not to explore in depth the nature of human insight formation, but we do argue that, as shown in Panel A of Figure 2, insight formation is the second key and necessary step along the pathway from BA Use to Organizational Benefits from BA.

8 With 1,000 "observations", i.e., rows of data in the spreadsheet, the estimated coefficients were much closer to the true values, and the p-values in cells K17, K18, and K19 were highly significant. 


\section{Decisions}

We now turn to the box labeled Decision(s) in Panel A of Figure 2. Decision-making, too, is an intensely human personal (and often group) activity. Akinci and Sadler-Smith (2012) and Eisenhardt and Zbaracki (1992) provide two excellent summaries of knowledge about human decision making. Akinci and Sadler-Smith (2012), in particular, take the reader on a guided tour of the evolution of world's understanding of how individual managers make decisions. Highpoints along their tour are the work of three Nobel Prize winners: (1) Simon's work on bounded rationality and his behavioral theory of organizational decision making, (2) Kahneman and Tversky's work on heuristic biases in human decision making, and (3) Sperry's work on the functional specialization of the cerebral hemispheres of our brains. Akinci and Sadler-Smith's (2012) summary of managerial decision making is complemented by Eisenhardt and Zbaracki's (1992) review of strategic decision making in organizations. Their conclusion is succinctly summarized as follows:

"It is clear that people are rational, but only boundedly so, that power wins battles of choice, and that chance affects the course of strategic decision making. It is also clear that a synthesis of bounded rationality and political perspectives provides a compelling description of strategic decision making." (Eisenhardt and Zbaracki, 1992, p.18)

Our point, again, is that like the preceding two steps in the process model in Panel A in Figure 2, the decision-making step is also an intensely human activity. It is by no means assured, for instance, that insights from analytics use will result in any intendedly value-creating actions at all, or if actions are taken, whether they will be guided by some earlier insight or by other interests. In proposing the process model in Panel A of Figure 2, we are arguing that Decision-making is the third key and necessary step along the pathway from BA Use to Organizational Benefits from BA.

\section{Intendedly value-creating actions}

The Intendedly value-creating actions in the process model in Panel A of Figure 2 were discussed earlier under the heading "The three paths in Panel A". As pointed out then, such actions normally require the use of many of the organization's other, non-BA, resources ${ }^{9}$. Our claim is that these Intendedly value-creating actions are the fourth key and necessary step along the pathway from BA Use to Organizational Benefits from $\mathrm{BA}^{10}$. The logic is: no actions taken, no value from BA!

9 Strictly speaking, therefore, the shorthand expression "Organizational benefits from BA use" is incorrect: the organizational benefits are the result of using many of the organization's resources. Our justification for using the shorthand expression is that BA-usage is regarded as the causal driver of the benefits. Ricardo (1817) used a similar shorthand when he attributed the economic rent from ownership of scarce highly productive corn-growing land to the land, and ignored the contribution of all the people and other resources needed to work the land to produce the corn and get it to market.

${ }^{10}$ In saying that the action step is always necessary, we treat inaction following a decision not to act in a way that had been previously planned as a type of action. 


\section{Summary: The Process Model in the BASM (Panel A in Figure 2)}

Analytics use sometimes leads to insights, insights inform decision making, and if those decisions lead to beneficial actions, they also lead to business benefits from BA use. Equally, if there are no insights, or insights do not lead to decisions that lead to beneficial actions, there will be no benefits from BA use. Further, the first three steps in the process shown in Panel A of Figure 2 are intensely human activities. Our first major knowledge claim in this paper is simply that the process depicted in Panel A of Figure 2 is fundamental to the realization of benefits from BA. Because no other academic researcher seems to have made a similar claim (certainly none of the academic authors whose models appear in online Appendix 1 has done so), we regard this model as the first major contribution of this paper.

We have one final point to make before leaving this discussion of the process model in Figure 2. This is that value from BA may be generated by many people in an organization, not just data scientists (Davenport and Patil 2012). For this reason, the words "executed over and over again in different parts of the organization" in Figure 2 are very important. Our argument is that (a) many, many people throughout an organization may have access to BA tools, (b) all of them may have useful insights, and (c) one million "ten-dollar" insights are worth as much as one "ten-million dollar" insight. In other words, repeated execution of the process in Panel A of Figure 2, by people all over the organization, is the fundamental driver of benefits from business analytics.

\section{The Variance Model in the BASM (Panel B in Figure 2)}

The variance model in the BASM (Panel B in Figure 2) presents a different, but complementary, explanation of how organizations use business analytics to create business value. It answers Research Question 2 by focusing on things that managers can do to help their organization realize greater business value from BA. In constructing this sub-model, we drew mainly on insights from Davenport and Harris (2007), Davenport et al.'s (2010) DELTA model, Watson and Wixom (2007), and Seddon et al.'s (2010) OBES model. All five factors from DELTA, all six factors from Watson and Wixom (2007), and three of the six factors from OBES are included in this model. The model-which is a special case of both Seddon et al.'s (2010) OBES model and Murer et al.'s (2011) enterprisearchitecture-planning approach applied to business analytics-argues that an important mechanism ${ }^{11}$ through which firms derive increased benefits from business analytics is through on-going BAimprovement projects. BA-improvement projects include both the implementation of new BI software (that delivers new analytics functionality) and initiatives that apply existing functionality to new areas of decision making.

${ }^{11}$ Here the word "mechanism" is used in the same sense as in Critical Realism (Bhaskar 1978). 
Apart from the Organizational Benefits construct, none of the concepts in this variance model is present in the process model. Yet as we now show, the constructs in the variance model provide an equally powerful explanation of how BA contributes business value. This is why we see the two views in the BASM as complementary.

The right-hand project side of the model in Panel B of Figure 2 hypothesizes, as H1-H4, that the greater the extent of functional fit (H1), ready availability of high-quality data (H2), analytical people (H3), and success in overcoming organizational inertia (H4) resulting from a BA-improvement project, the greater the organization's success in realizing benefits from that project. The left-hand side of Panel B hypothesizes that in the long term, it is analytic leadership (H5), the adoption of an enterprise-wide analytics orientation (H6), the selection of well-chosen targets (H7), the extent to which evidence-based decision making is embedded in the "DNA" of the organization (H8), and execution of multiple BA-improvement projects (possibly over many years) (H9) that drive benefits from business analytics. Each of these hypotheses is now explained and justified in turn.

\section{Hypothesis Development (Hypotheses 1-9)}

It is hypothesized in the BASM that variance in Organizational Benefits from Analytics Use (with Use being as described in the process model section, and Benefits being assessed from the perspective of senior management) is driven by variance in each of the nine independent variables defined in Table 2 and discussed below.

[Table 2 goes here]

\section{Functional fit}

As defined in Table 2, row 16, Functional fit (FF) is "the extent to which the functionality provided by the BA platform matches the functionality that the organization needs to access and analyze data effectively and efficiently". This concept is very similar to Clark et al.'s (2007) "Management Support Systems Functionality". Our FF concept comes from Seddon et al. (2010), who argue that "organizations invest in ES for their functionality" ("ES" being "enterprise systems"). Similarly, we argue here that the fitness for purpose of functionality provided by BI toolset, e.g., for business and ad hoc queries, fixed reports, dashboards, OLAP, and/or visualization (Howson 2011), is an important determinant of the benefits that an organization can derive from a BA-improvement project (post golive). Such projects might involve either the implementation of new software to deliver new BI functionality to the organization, or initiatives that apply existing (and possibly unused) functionality to a new area of decision making. Further evidence of the importance of functional fit is that two of the three most significant path coefficients reported by Işik (2010) in her $n=111$ survey on BI Success were related to Functional fit (her H1e Flexibility and H2a User Access Quality). Since toolset functional fit 
helps to determine benefits that flow from each BA-improvement project, it is hypothesized that:

H1: The greater the Functional fit (FF) resulting from each BA-improvement project, the greater the Organizational Benefits from BA Use.

Note that current vendor interest in products such as SAP HANA, Oracle Exalytics, and Every Angle suggests that an important attribute of functional fit is speed of access to information. The massive reductions in the time to access information, e.g., from hours to minutes, enabled by such products make it more likely that decision makers with ready access to such tools will search for information to support decision making more frequently than those without such access, and so derive more value from business analytics.

\section{Readily available high-quality data}

As defined in Table 2, row 17, Readily available high-quality data is "The extent to which relevant and accurate data are readily available for analytics use, from sources both within and external to the organization". According to Davenport et al. (2010, p.23), data are "the prerequisite for everything analytical", and "You can't be analytical without data and you can't be really good at analytics without really good data." They also argue that appropriate governance arrangements need to be in place to ensure data accessibility. Watson and Wixom (2007) and Sabherwal and Becerra-Ferandez (2011) make a similar point. For example, Watson and Wixom (2007, p.98) say that a key to BI success is that "There is a strong decision support data infrastructure". Since readily available high-quality data is likely to vary from BA-implementation project to project, it is hypothesized that:

H2: The greater the extent of readily available high-quality data available for each BA-improvement project, the greater the Organizational Benefits from BA Use.

\section{Analytical people}

As defined in Table 2, row 18, the variable, Analytical people, is "The extent to which there are people within the organizational unit with an analytic mindset who help drive business value from BA." Such people include Davenport et al.'s (2010, pp.91-98) analytical champions, professionals, semiprofessionals, and amateurs. According to Davenport and Harris (2007, p.131), "It is people who make analytics work and who are the scarce ingredient in analytic competition", not the organization's access to, for example, high-powered data-mining tools. Since the availability of capable analytical people is likely to vary from project to project, it is hypothesized that:

H3: The greater the quality of analytical people available on each BA-improvement project, the greater the Organizational Benefits from BA Use. 


\section{Overcoming Organizational Inertia}

As defined in Table 2, row 19, Overcoming Organizational Inertia (OOI) is "The extent to which members of the organization have been motivated to learn, use, and accept the new system". This concept comes from Seddon et al. (2010), who argue that "no matter how good the technical system, unless people in the organization are motivated to use the system, and have sufficient knowledge of how to use the system effectively (Purvis et al. 2001), the organization is unlikely to gain the benefits it might from the system". In a similar vein we argue here that if a BA-improvement project is intended to result in a system that users in some part of the organization must be persuaded to learn and use, the organization's success in overcoming organizational inertia will be a key determinant of benefits from that BA project. Watson and Wixom (2007, p.98) make a similar point when they say that a key to BI success is that "Users have the necessary tools, training, and support to be successful”. Further, since the organization's success in overcoming organizational inertia is likely to vary from project to project, it is hypothesized that:

H4: The greater the success in Overcoming Organizational Inertia (OOI) in each BA-improvement project, the greater the Organizational Benefits from BA Use.

The significant path coefficient of $0.33(n=419, p<0.001$, from 347 organizational units) between operational managers' Absorptive Capacity (a characteristic of the people using BI) and BI Assimilation (a measure of business benefits attributed to use of BI) reported by Elbashir et al. (2011) lends further support for the likely validity of $\mathrm{H} 3$ and $\mathrm{H} 4$.

\section{Analytic Leadership}

As defined in Table 2, row 11, Analytic Leadership is "The extent to which people in any organizational unit take leadership of initiatives or projects to increase use of business analytics for organizational gain". With respect to leadership, Davenport et al. (2010, p.57) say: "If we had to choose a single factor to determine how analytical an organization will be, it would be leadership.... Leaders have a strong influence on culture and can mobilize people, money, and time to help push for more analytical decision making." In a similar vein, Watson and Wixom (2007, p.98) say a key success factor for BI success is that "Senior management believes in and drives use of BI." Since analytic leadership seems so important for the realization of benefits from BA, across projects, not just for individual projects, it is hypothesized in the BASM that:

H5: The greater the extent of analytic leadership in the organization, the greater the Organizational Benefits from BA Use.

\section{Enterprise-wide Analytics Orientation}

As defined in Table 2, row 12, an Enterprise-wide Analytics Orientation is "The extent to which the 
organization has adopted an enterprise-wide orientation to the use of business analytics". The definition in Table 2 further explains that 'Such an enterprise-wide view is normally supported by an integrated BI platform that provides "a single, holistic view of the company" (Davenport et al. 2010, p.45) rather than, for example, multiple datamarts'. Davenport et al. (2010, Ch.3) argue forcefully that an enterprise-wide view of the role of BA is critical to BA's success. "To develop an enterprisewide view of analytics, a company must do more than integrate data, combine analysts, or build a corporate IT platform. It must eradicate all of the limited, piecemeal perspectives harbored by managers with their own agendas, needs and fear-and replace them with a single, holistic view of the company." (Davenport et al. 2010, p.45). This same message appears again in Davenport et al.'s (2010) Ch.7, where they make the point that organization-wide optimization of business processes is often more valuable than local optimization, and organization-wide optimization requires an enterprise-wide analytics orientation. Since an enterprise-wide analytics orientation seems so important for the realization of benefits from BA, across projects, not just for individual projects, it is hypothesized that:

H6: The greater the extent to which the organization has adopted an Enterprise-wide Analytics Orientation the greater the Organizational Benefits from BA Use.

\section{Well-chosen targets}

As defined in Table 2, row 13, Well-chosen targets is "The extent to which targets for new analytics initiatives are selected carefully based on the combination of their business potential and whether the necessary resources, including data, are available (Davenport et al. 2010, Ch.5)". For a firm new to analytics, Davenport et al. (2010, p.73) suggest that a specific business problem might be a good target. For more analytically advanced organizations, the best targets, according to Davenport et al. (2010), will be those that help the organization enhance the distinctive resources that provide it with competitive advantage. Watson and Wixom (2007, p.98) similarly draw attention to the need for well-chosen targets when they say that BI is more successful if "There is alignment between the business and BI strategies", and "There is effective BI governance". In a similar vein, Sabherwal and Becerra-Fernandez (2011) argue that BI governance processes, e.g., articulation of BI principles, and creation of a BI Steering Committee, are important drivers of benefits from BI. Finally, from Murer et al.'s (2011) perspective, well-chosen targets should also increase future BI agility as well as producing business value today. Since choosing sound targets for future initiatives is clearly a key driver of future BI benefits, it is hypothesized that:

H7: The sounder the governance processes for selecting (well-chosen) targets for future BI initiatives, the greater the Organizational Benefits from BA Use. 


\section{Extent to which evidence-based decision making is embedded in the "DNA" of the organization}

In the BASM, the construct Extent to which evidence-based decision making is embedded in the "DNA" of the organization (Table 2, row 14) is an attempt to assess the extent to which evidencebased decision making is embedded in the core values and processes of the organization. Kettinger et al. (2011) describe this concept as the firm's Information Orientation. Howson (2008) and IDC (Vesset and McDonough 2009) call it Pervasive BI. In the first Davenport book on BA, Davenport and Harris (2007) describe firms where evidence-based decision making has become the very basis of their competitive advantage as "analytic competitors": "We define an analytical competitor as an organization that uses analytics extensively and systematically to outthink and outexecute the competition" (p.23). However, as Davenport et al. (2010, p.vii) point out in the preface to their second book, their first book was about "the earliest and most aggressive adopters of analytics". Many other firms, they explain in their second book, just want to know how to become more analytical. The implication of these comments is that as organizations become more analytical (i.e., as evidence-based decision making becomes more and more deeply embedded in their "DNA") they will realize increasingly more benefits from their use of BA. Similar arguments are presented in Kettinger et al. (2011), Accenture (2011), LaValle et al. (2011), and Watson and Wixom (2007). For example, Watson and Wixom (2007, p.98) say that BI is more successful when "The use of information and analytics is part of the organization's culture". In terms of barriers to the use of analytics, Accenture's 2010 global survey of 800 "directors and senior managers" reported that "corporate culture still presents a major barrier" to the wider use of customer "analytics and fact based decision making" (Accenture 2011). The above insights are summarized in the following hypothesis:

H8: The greater the extent to which evidence-based decision making is embedded in the "DNA" of the organization, the greater the Organizational Benefits from BA Use.

\section{On-going BA-improvement projects}

Finally, as defined in Table 2, row 15, On-going BA-improvement projects is "A measure of the number and extent of investment in BA-improvement projects. Such projects include both the implementation of new BI software (that delivers new analytics functionality) and initiatives that apply existing functionality to new areas of decision making." The claim that On-going projects is a source of business value builds on the work of Seddon et al. (2010), who argue that the primary driver of benefits from Enterprise Systems (ES) is "on-going improvement projects that deliver new functionality to users." A similar idea is discussed by Murer et al. (2011) in the context of enterprise architecture, e.g., see their Figure 7.1, p.204. The importance and beneficial consequences of ongoing BA projects are clearly evident in Shanks and Bekmamedova (2012a, b). 
In Seddon et al. (2010), new functionality is delivered by projects that implement new ES software. In the BASM in Figure 2, we have extended the project concept to include both (i) projects that implement new BA software, and (ii) projects that using existing software in new ways or in new areas, called new initiatives. The benefits driver in both cases is the running of new projects. This insight-that BA-improvement projects are likely to be a primary driver of new analytics resources that, in turn, deliver new benefits-is captured in the following hypothesis:

H9: The greater the organization's investment in on-going Business Analytics-improvement projects, the greater the Organizational Benefits from BA Use.

\section{Summary}

The Business-Analytics Success Model (BASM) model in Figure 2 is a synthesis of many ideas from the BA literature, as well as from the broader IS, Psychology, and Management literatures. It is an attempt to identify the most important mechanisms through which organizations achieve business value from business analytics, and to place them as logically as possible in a well-defined model. In terms of context, the BASM views organizations and their subunits as acting like living things within a highly competitive environment, where those living things need information to know how to react to changes in that environment (Beer 1972, 1984).

The BASM presents two different, though mutually compatible, perspectives to explain how use of business analytics contributes to business value. First, the process model in Panel A of Figure 2 shows the focal organization's use of its BA resources to conduct routine and non-routine analyses of both internally and externally-sourced data to contribute to business value by revealing insights that lead to decisions to take intendedly value-creating actions. Some of these actions (path 2 in Panel A) lead to changes in organizational resources, but as pointed out by Shanks and Bekmamedova (2012a,b), many use existing resources (path 1) to produce business value. The process in Panel A is executed over and over by different people in different parts of the focal organization.

Second, in addition to the preceding "process" view, the BASM also offers a variance-model explanation of how firms use BA to create business value. In the variance model, it is argued that in the long term the key to achieving greater business value from BA is to have strong analytical leadership (H5), adopt an enterprise-wide orientation (H6), direct resources towards high-return targets (H7), and embed a positive attitude to evidence-based decision making in the "DNA" of the organization (H8). In addition, the BASM argues that these four drivers will induce managers in the focal organization to embark on new BA-improvement projects, either to implement new BI resources, or to use BI in new ways (H9). For each of these projects, success in generating business value, the BASM argues, is likely to be higher if the new capabilities are a good fit with business needs (H1), high-quality data are readily available (H2), the organization has the analytic-people capabilities to 
use the BI tools available (H3), and training and change management are used to support any changes in work practices required to use new systems (H4).

As an example of the application of this "projects" side of the BASM, if the project involves developing, say, a new dashboard for assessing credit risk of customers in the Finance department of a merchant bank, the model asserts that it is the specific dashboard functionality delivered (H1), the ready availability of relevant high-quality data (H2), the analytic capabilities of the Finance-department staff (not others elsewhere in the organization) (H3), and the capacity and motivation of dashboard users to learn to use the new functionality (H4) that will drive benefits from the project. Further, the organization's capacity to execute this dashboard-implementation project, and to absorb the changes in work practices that flow from it, is an example of a dynamic capability (Teece et al. 1997; Path 2 in Panel A of Figure 2). Finally, once the organization has gone live with its new dashboard system, benefits from use will flow from repeated execution of the process depicted in Panel A of Figure 2.

Although many variance models of factors affecting realization of organizational benefits from BA have been published (see models 5 to 16 in Online Appendix 1), no other researcher seems to have developed as comprehensive a variance model as that shown in Panel B in Figure 2. We therefore regard this variance model as the second major contribution of this paper.

\section{Preliminary Assessment of the Validity of the BASM: Methodology}

To conduct a preliminary assessment of the validity of the BASM (Figure 2), we downloaded a series of BA customer-success stories from various vendor websites and examined those stories to see how frequently concepts and relationships identified in the BASM were discussed in those stories in a manner consistent with the model. The reasoning behind this method of assessment is that in their attempts to convince potential purchasers of the value of buying their software, vendors are likely to discuss the things that they think are most important to the realization of benefits from their software. Vendors are also particularly well placed to understand factors affecting benefits from BA, because they discuss these factors with their customers on a daily basis over many years. Therefore, a good model should highlight things that are mentioned frequently in the vendors' customer-success stories.

The downside of using vendors' customer-success stories is that such stories always paint a rosecolored picture of the use of the vendor's software. However, success stories are built on a scaffolding of facts about people and processes that can be used, with care, to gain much easier access to a wide range of $\mathrm{BI}$-using organizations than is possible through, say, organizing and conducting case studies or surveys oneself. For example, Işik (2010) reported a disappointingly low (less than 1\%) response rate to a survey mailed out to over 11,000 "corporate and IS buyers of business intelligence". Thus in this study, as an alternative to a survey, we used vendor-published BA customer-success stories as our source of data. Seddon et al. (2010) used a similar method in their preliminary test of their OBES

This article is protected by copyright. All rights reserved. 
model, published in MIS Quarterly.

\section{Characteristics of the sample}

Our sample of customer-success stories was gathered by visiting major BI-vendor websites and looking for success stories related to the use of analytics to create business value. We found that socalled "case studies" from IBM, SAP, and Teradata were the most useful because they were typically longer than those of other vendors. Stories from other vendors, e.g., Oracle, MicroStrategy, and SAS, were less comprehensive and therefore less useful for our purpose. Customer-success stories were selected when they discussed some aspect of the use of business analytics. In other words, stories focusing on just technology or implementation, but not use, were excluded. Using these criteria, we downloaded 160 customer-success stories. These stories cover use of business analytics in a wide range of different sized, mainly US-based firms, from a wide range of industries and government. From these stories we used a random-number generator to select 100 stories for analysis for this paper $^{12}$. The resulting sample contained 39 stories from IBM, 28 from SAP (including seven 20minute videos from SapphireNow), 19 from Teradata, plus a handful from each of Information Builders, Microsoft, and Qliktech). In total, the data consisted of over 410 pages of text, seven 20minute videos, and 98 PowerPoint screens. A good example of a customer-success story is a sevenpage article from IBM Cognos on Sharp HealthCare (IBM, 2010) discussed in the next section.

\section{Coding}

For our preliminary assessment of the validity of the BASM, two coauthors first worked together to code a small number of examples from the 100 selected. Both coders then worked independently coding the remaining stories, meeting three times to discuss and reconcile codes. We used a spreadsheet with one row per success story, and 18 columns for the 18 concepts in the BASM to record results of our analysis. For each story, coding involved asking whether any of the 18 concepts in the BASM, e.g., analytic leadership, readily available high-quality data, etc., was mentioned in the success story in a way that was consistent with its use in the model. If the answer was Yes, a ' 1 ' was placed in spreadsheet in the cell for that concept (column) for that success story (row). If a concept was not mentioned in the success story in a manner consistent with the model, a zero was placed in the cell. Occasionally, if the evidence was present, but weak, we scored the strength of evidence as 0.5 , not 1. Apart from the spreadsheet, no other software was used for coding. The initial level of agreement between the coders was $76 \%$. After discussing differences, agreement increased to $98 \%$. Final

12 We restricted our analysis to only 100 stories, because the pattern of percentages in the Results table, Table 4, was already evident after 50 stories had been coded. That pattern had hardly changed after 100 stories had been coded, so we decided to stop coding at that point. Details of all 100 success stories analyzed are presented in online Appendix 3. 
decisions on the last $2 \%$ were made by the lead author of this paper. After coding was complete, totals for each column were used to calculate the percentage of success stories that contained mention of a construct from the BASM in a way that was consistent with the model.

To illustrate these coding judgments, consider the Sharp Healthcare example in Figure 5. First, the story describes a two-year project led by Vonda Brown, Manager, Decision Support Systems, to replace hundreds of Excel spreadsheets and Access databases by a central data warehouse (p.2):

"The data warehouse unites charge, expense, revenue and clinical information-from clinic, medical group, hospital, lab, pharmacy, physician orders, vital signs, allergies, immunizations, operating room, encounters and referral data-into one place to make operational decisions easier and more effective."

[Figure 5 goes here]

This was clearly an enterprise-wide software-implementation project, led by a key manager, that affected the work practices of many people at Sharp Healthcare. So there was a good fit between the project-oriented view the BASM inherited from Seddon et al. (2010), and the success story as told by IBM. Second, the "Key Benefits" section of Figure 5 says that BI is now being used in this organization as an integrated reporting tool for improving organizational effectiveness, not as the primary basis for competition like the case studies in Davenport and Harris (2007). So, again, there was a good fit between the "operational use of BA" view the process model in the BASM inherited from Shanks and Bekmamedova (2012a,b) and this success story from IBM.

Turning now to the detailed coding, we treated comments in the text of the success stories as evidence of support or otherwise for different parts of the model. As "outside researchers" (Walsham 2006), our analysis was of the printed text. However, we relied on our own understanding of the situations described to interpret the words on the pages. Examples of coding are shown in Table 3. The text was presumably written by marketing people at IBM, and the quotations are from Vonda Brown, the Decision Support Systems manager, and Carol Wanke, Director, Patient Financial Services, for Sharp Healthcare. There is not enough space in this paper to present examples of all coding even for this single success story, but Figure 5, the quotation above, and the 13 examples in Table 3 show the nature of the evidence used. The reader is encouraged to read the actual success story ${ }^{13}$ for more details.

[Table 3 goes here] 13 http:// locussolutions.com/ wp-content/ uploads/ 2015/ 03/Case-study-Sharp-Healthcare.pdf (viewed
Nov 2015) 


\section{Results}

Results from our analysis of the 100 vendor-sourced business-analytics success stories are summarized in both Table 4 and Figures 6 and 7. The table reports the percentages of times that the various concepts from the BASM in Figure 2 were mentioned in the success stories in a way that was consistent with the model.

[Table 4 goes here]

\section{Process Model}

With respect to the process model (rows 1-10 in Table 4), we expected that all the stories would report that BA Resources (technology and analytical people) were being used to produce insights leading to decisions and actions that-in conjunction with each organization's many non-BA resources-led to Organizational benefits. The high percentages (above 75\%) for seven of the nine constructs in Figure 6 are consistent with this expectation. Given that all the success stories came from technology vendors, it is no surprise that $100 \%$ of stories mentioned Enabling technology. The implications of the two low percentages ( $6 \%$ in row 5 and $12 \%$ in row 8 of Table 4 ) are discussed shortly.

[Figure 6 goes here]

\section{Variance Model}

With respect to the variance model (rows 11-19 in Table 4), given the strength of Davenport et al.'s (2010) arguments about the importance of the factors in their DELTA model and Seddon et al.'s (2010) claims about the importance of the factors in their OBES model, we expected strong support for all hypotheses except for H8 (row 14), where Davenport et al. (2010) had already reported that few firms that they studied were "analytic competitors". However, the results in Table 4 and Figure 7 show high percentages (above 75\%) for only five of these nine hypotheses. There was strong support for four of Davenport et al.'s five DELTA factors, namely, Data (H2, row 17, 86\%), Enterprise-wide orientation (H6, row 12, 76\%), Leadership (H5, row 11, 92\%), and Targets (H7, row 13, 88\%), but support was weak for DELTA's fifth factor, Analytical people (H3, row 18, 13\%). There was also strong support for one of Seddon et al.'s three factors, namely Functional Fit (H1, row 16, 89\%), but support was weaker for the two other factors from OBES, On-going improvement projects (H9, row 15, 44\%) and Overcoming Organizational Inertia (H4, row 19, 35\%).

[Figure 7 goes here]

\section{Discussion}

What are the implications for the BASM of the cells with low percentages in Table 4? One way of interpreting the percentages in Table 4 is that they are all above zero, which means that there was 
evidence in at least some success stories that all constructs in the BASM are helpful for understanding how BA contributes to business value. However, this does not explain why six of the 18 percentages in Table 4 are so much smaller than the others. Our explanations for the six low percentages, and their implications for the BASM, are as follows:

Row 5: Only 6\% of organizations in our sample made changes to organizational resources flowing from use of BA. This is consistent with Shanks and Bekmamadova's (2012) punctuatedequilibrium model where firms made occasional changes to BA resources then used the resulting resources for months before changing them again. It is also consistent with the Tesco example discussed earlier. However, the change-resources path (path 2 in Panel A of Figure 2) was sometimes taken, and when it was, it led to important changes, e.g., reduction in staff. Therefore, we decided that the Change resources path is a meaningful option, and is worth retaining in the BASM.

Rows 8 and 18: Only $12-13 \%$ of success stories in our sample made reference to analytical people (defined in row 18 of Table 2). The success stories frequently report people gaining insight from their use of BI tools, but as with H8 (row 14, discussed next), they don't often discuss whether those people have analytic mindsets. Clearly, specialist analysts are required to use sophisticated BI tools, e.g., data mining, so the concept of analytical people is valid and worth retaining in the BASM. But it appears that the extent to which regular users of analytic tools are "analytic people" is not something that vendors have chosen to discuss much in their success stories. Due to the importance of analytical people in our process model, we have decided that it is a construct worth retaining in the BASM.

Row 14 (H8): As noted above, Davenport et al. (2010) have already reported that few firms that they studied in their second study were "analytic competitors". It is no surprise, therefore, that only $14 \%$ of firms in our sample showed evidence of an organization-wide commitment to analytics. However, the fact that some did, and that consultants talk of "pervasive BI" (Howson 2008), shows the value of having H8 (which is inherited from both Davenport \& Harris (2007) and Davenport et al. (2010)) in the BASM. So we have decided to retain this construct in the BASM.

Row 15 (H9): Only 44\% of success stories in our sample discussed on-going improvement projects. This percentage was smaller than expected, but 44 organizations is more than enough to show that this concept can be an important driver of organizational benefits from BA. Therefore, both this construct and $\mathrm{H} 9$ are worth retaining in the BASM. Importantly, the evidence that $44 \%$ of success stories discussed multiple projects also demonstrates the merit of structuring the BASM variance model in two parts: long-term and project-by-project. If few organizations ran multiple projects, there would be little reason for structuring the BASM variance model in two parts. 
Row 19 (H4): Only 35\% of organizations in our sample discussed efforts to overcome organizational inertia. This percentage was also smaller than expected, but 35 organizations is still more than enough to show that this concept can be an important driver of organizational benefits from BA. Therefore, both this construct and $\mathrm{H} 4$ are worth retaining in the BASM.

In addition to asking whether factors included in the BASM were discussed in the vendors' businessanalytics success stories, it is also important when assessing a model to ask whether there were any factors mentioned in the stories that are not captured in the BASM or concepts that were not meaningful. Here, we have three insights to share. First, a type of benefit not captured in the current BASM is that implementation of BI tools often enables users to develop their own reports, which reduces pressure on the IT department to create new reports. This user-self-service benefit to IT was frequently reported, and needs to be factored into future versions of the BASM. Second, two success stories discussed the use of BI resources by their organization's customers, not their own employees. For example, the speaker from Omnicom OMD explained that OMD's BI/ Dashboard offering had been "a key differentiator in major client account wins" (LoFrumento 2011, slide 18). To support this claim, he quoted Nancy Bhagat, Intel's VP of Sales and Marketing, who said of Intel's new \$300million media contract: "Each of the finalists impressed us, but OMD gave us a stronger sense of possessing world-class media-industry leadership and state-of-the-art business intelligence and analytics" (McIlroy 2008). Use of BI resources as a product, or for product differentiation, was not considered when the BASM in Figure 2 was formulated. It makes one think of users and data scientists working outside the focal organization. Third, it is clear from the success stories that different users use different BI tools in very different ways. Drilling down into these different patterns of tool use would be helpful. In future work, it would be useful to try to extend the BASM to reflect these three insights.

Overall, despite these suggested areas for improvement, there is strong support for the existing BASM in the vendors' customer-success stories. In other words, the current BASM appears to provide a solid basis for future model development. Further, because the sample used for this preliminary assessment of the validity of the BASM comes from a broad range of organizations, we would expect it to be applicable to a wide range of organizations in different industries and countries.

\section{Limitations}

The BASM in Figure 2 is the result of our attempt at sifting through the literature, then integrating and summarizing insights from many prior researchers (e.g., see those in the online Appendix 1, but also the broader IS, Psychology, and Management literatures) about the mechanisms through which organizations realize benefits from BA. It is unlikely to be perfect. The major difficulties in such an exercise are (a) deciding which ideas appear to be the more important, and (b) integrating them into a 
coherent whole. In making the choices we did, we were also informed by the work of non-BA researchers, e.g., Pretz et al. (2003), Sternberg and Davidson (1996), Akinci and Sadler-Smith (2012), Eisenhardt and Zbaracki (1991), Barney (1991), Teece et al. (1997), and Beer (1972, 1984).

It seems to us that the best way to assess the result of all these judgments is empirically. That is why we decided to analyze the 100 vendor-supplied BA-customer success stories. However, the assessment we conducted is very preliminary. Much further work is still needed to assess the validity of the BASM. It seems to us that the process model is very strong, however the structure and choice of factors for the variance model may need more work. In particular, Quality of the BA platform is not a factor in the variance model, yet it is a frequently mentioned factor in prior research (see Appendix 1). Organization size and Industry may also be useful controls to add to any quantitative test of the model $^{14}$

Finally, many of the more human-oriented aspects of the BASM (analytical people (H3); overcoming organizational inertia (H4); and decision-making culture (H8)), received only modest support from the vendor-sourced success stories. By contrast, the more technology-oriented factors (enabling technology; well-chosen BA-project targets (H7); functional fit (H1); and high-quality data (H2)) received stronger support. This is probably another limitation of relying on vendor-sourced success stories, which understandably tend to focus more on the technology (i.e., the vendor's product offerings), than people. Future empirical research using primary data collection to test the BASM would help overcome this limitation.

\section{Conclusion}

As mentioned in the Introduction (and illustrated in Appendix 1), many models of factors that drive benefits from BI and BA have now been published. Some are very complex, e.g., Clark et al.'s (2007) model summarizes an extremely comprehensive review of the management-support-systems (MSS) literature. Some are very high-level, e.g., Elbashir et al. (2011) who used highly abstract concepts, such as absorptive capacity, to explain BI assimilation. Some are very simple, e.g., Işik (2010) found some simple empirical relationships between technical and organizational BI resources and BI success. And some are very implementation-project focused, e.g., Wixom and Watson (2001). However, most of these models are so different that it is hard to identify any emerging consensus.

In an effort to consolidate what is known, our goal in this paper has been to create a model that captures many of the key insights from the BA literature. We have also tried to extend that literature by adding insights from the psychology, management, and IS literatures. In our opinion, the two-part BASM in Figure 2-together with the two tables of definitions, the description of the process model, and justifications of hypotheses in the variance model-provides a better explanation of what firms

${ }_{14}$ Thanks to an anonymous review for this point. 
need to do to realize greater benefits from BA than any prior work with which we are familiar (i.e., the 16 models in Appendix 1), and is thus the primary contribution of the paper. Finally, although much more rigorous testing is clearly necessary, the empirical results summarized in Table 4 and Figures 5 and 6-which provide preliminary support for the model-are also a useful, though minor, contribution.

We hope that other researchers will be able to take and extend our ideas, and conduct further tests of the BASM or similar models. Testing of the process model would probably best be done by in-depth case studies. One might begin by asking BA-users, especially data scientists, to think of times when they have gained insight from use of BA, then to follow through to see whether the business had realized benefits from these insights. Alternatively, one might start with instances of claimed benefits from BA and work back to see what sorts of insights (and whose insights) had preceded them. In both cases, the BASM process model provides a template for the expected pathways to benefits. Variance models are probably better suited to cross-sectional testing, so the best way to test the BASM variance model may be through surveys. For such testing, researchers might use the definitions in Table 2 to develop questions for a survey instrument that could then be sent to knowledgeable people (e.g., the senior person responsible for BA) in an appropriate sample of firms. The unit of analysis for the survey might be BA efforts in the firm overall, or individual BA-improvement projects (in most firms, one would expect a number of them). These efforts would provide clearer evidence of the validity or otherwise of the various parts of BASM. This would, in turn, help managers, students, and fellow researchers gain a clearer understanding of how firms realize business value from business analytics and what they need to do to realize greater value in future.

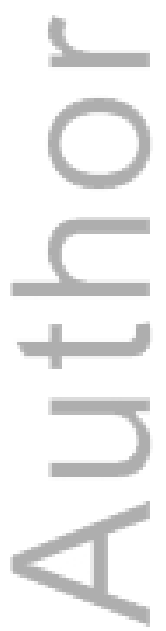




\section{References}

Accenture (2011). Customer Experience Suffers As Organizations Make Inconsistent Use of Analytics, Accenture Research Finds, https:// newsroom.accenture.com/subjects/analytics/customerexperience-suffers-as-organizations-make-inconsistent-use-analytics-accenture-researchfinds.htm (viewed Nov 2015).

Accenture (2012). The Analytics J ourney to ROI. http:// www.accenture.com/us-en/ Pages/insightanalytics-journey-roi-insights-summary.aspx (viewed August 2014)

Akinci, C., and Sadler-Smith, E. 2012. "Intuition in Management Research: A Historical Review," International J ournal of Management Reviews (14:1), pp. 104- 122.

Albright, S. C., Winston, W. L., \& Zappe, C. J. (2010). Data analysis and decision making with Microsoft Excel. South-Western Publishing.

Amabile, T. M. (1983). The social psychology of creativity: A componential conceptualization. J ournal of personality and social psychology, 45(2), 357-376.

Barney, J. B. (1991). "Firm Resources and Sustained Competitive Advantage," Journal of Management (17:1), pp. 99-120.

Barney, J.B., Ketchen D.J., and Wright, M. (2011) "The Future of Resource-Based Theory: Revitalization or Decline?," J ournal of Management 37(5) pp.1299-1315.

Beer, S. 1972. Brain of the Firm. Allen Lane, London: Penguin Press, First Edition.

Beer, S. 1984. "The Viable System Model: Its Provenance, Development, Methodology and Pathology," The J ournal of the Operational Research Society (35:1), pp. 7-25.

Bhaskar R (1978). A Realist Theory of Science. Hassocks, Sussex: Harvester, UK.

Bowden, E. M., J ung-Beeman, M., Fleck, J ., \& Kounios, J . (2005). New approaches to demystifying insight. Trends in Cognitive Sciences, 9(7), 322-328.

Clark T. D., Jones, M. C., and Armstrong, C.P. (2007). "The dynamic structure of management support systems: Theory development, research focus and direction," MIS Quarterly (31:3), pp. 579-615.

Daft, R. L., and Weick, K. E. (1984). Toward a model of organizations as interpretation systems. Academy of Management Review, 284-295.

Davenport, T.H. and Dyché, J. 2013. Big Data in Big Companies, International Institute for Analytics

Davenport, T. H., Harris, J. G., and Cantrell, S. (2004). Enterprise systems and ongoing process change. Business Process Management J ournal, 10(1), 16-26.

Davenport, T. H., and Harris, J . G. 2007. Competing on Analytics, Cambridge, MA: Harvard Business School Press.

Davenport, T. H., and Harris, J. G., and Morison, R. (2010). Analytics at Work, Cambridge, MA: Harvard Business School Press.

Davenport, T. H., and Kim, J . (2013). Keeping up with the Quants, Cambridge, MA: Harvard Business School Press

Davenport, T. H. and Patil D. J . (2012), Data Scientist: The Sexiest J ob of the 21st Century, Harvard Business Review October, pp.70-76

Davidson JE and Sternberg RJ eds. 2003. The Psychology of Problem Solving, Cambridge University Press.

DeLone, W. H., \& McLean, E. R. (1992). Information systems success: the quest for the dependent variable. Information systems research, 3(1), 60-95.

Dominowski, R. L. and Dallob, P. (1996), Insight and Problem Solving, in Sternberg RJ and Davidson JE eds. The Nature of Insight, The MIT Press, 1996, pp.33-62

Eisenhardt, K. M., and Zbaracki, M. J. 1992. "Strategic Decision Making," Strategic Management J ournal (13:S2), pp. 17- 37.

Elbashir, M., Collier, P., and Sutton, S. (2011). "The role of organizational absorptive capacity in strategic use of business intelligence to support integrated management control systems." The Accounting Review (86), pp. 155-184.

Gregor, S. (2006). The nature of theory in information systems. MIS Quarterly, 30(3), 611-642.

Gruber H. E. (1996). Insight and Affect in the History of Science, in Sternberg RJ and Davidson JE eds. The Nature of Insight, The MIT Press, 1996, pp.397-431. 
Hagerty, J., Sallam, R. L., and Richardson, J. (2012). Magic Quadrant for Business Intelligence Platforms, Gartner document G00225500, 6 Feb 2012

Hartono, E., Santhanam, R., \& Holsapple, C. W. (2007). Factors that contribute to management support system success: An analysis of field studies. Decision Support Systems, 43(1), 256-268.

Helfat, C. E., Finkelstein, S., Mitchell, W., Peteraf, M. A., Singh, H., Teece, D. J., and Winter, S. G. (2007). Dynamic Capabilities: Understanding Strategic Change in Organizations, Carlton, Blackwell

Holsapple, C. Anita Lee-Post, and Ram Pakath (2014). A unified foundation for business analytics, Decision Support Systems, 64, pp.130-141.

Hopkins, M. S. (2010). "Interview with Eric Brynjolfsson: The four ways that IT is innovation," MITSloan Management Review (51:3), pp. 51-56.

Howson, C. 2008. "The Road to Making BI Available to Everyone," Information Week, Feb 23, 2008. http:// www.informationweek.com/news/ 206801074 (viewed Nov 2015).

Howson, C. 2011. "BI Scorecard Strategic and Product Summary Q3 2011." ASK LLC d.b.a. BI Scorecard, www.BIScorecard.com

IBM (2010). Case Study: Sharp HealthCare gets ahead of the curve:Performance management with IBM Cognos software, http:// public.dhe.ibm.com/common/ssi/ecm/ en/imc14503caen/ IMC14503CAEN.PDF (viewed J une 2013).

IBM (2015). IBM PureData System, https:// www-01.ibm.com/software/ data/puredata/ (viewed Nov 2015)

Issik, Ö. (2010). Business Intelligence Success: An Empirical Evaluation of the Role of BI Capabilities and the Decision Environment, Doctoral Dissertation, University of North Texas, http://digital.library.unt.edu/ark:/67531/metadc30472/m2/1/high_res d/dissertation.pdf (viewed Nov 2015).

Kettinger, W. J., Zhang, C., and Marchand, D. (2011). "CIO and Business Executive Leadership Approaches to Establishing Company-wide Information Orientation," MISQ Executive (10:4), pp. 157-174.

LaValle, S., Lesser, E., Shockley, R., Hopkins, M. S., and Kruschwitz, N. (2011). Big data, analytics and the path from insights to value. MIT Sloan Management Review, 52(2), 21-32.

Langley, A. (1999). Strategies for theorizing from process data. Academy of Management review, 24(4), 691-710.

Langley, A., Smallman, C., Tsoukas, H., \& Van de Ven, A. H. (2013). Process studies of change in organization and management: unveiling temporality, activity, and flow. Academy of Management J ournal, 56(1), 1-13.

Liberatore, M. J., \& Luo, W. (2010). The analytics movement: Implications for operations research. Interfaces, 40(4), 313-324.

LoFrumento, T. (2011). "Bringing Business Intelligence to the Media Industry," SapphireNow presentation 2011, http:// events.sap.com/ sapphirenow/ en/ session/613 , (viewed Nov 2015).

Loshin, D. (2012). Business intelligence: the savvy manager's guide. Morgan Kaufmann Pub.

Mayer R. E. (1996). The Search for Insight: Grappling with Gestalt Psychology's Unanswered Questions, in Sternberg RJ and Davidson JE eds. The Nature of Insight, The MIT Press, pp.3-32.

MoGuire, T. (2013). Making data analytics work: Three key challenges, Insights \& Publications, McKinsey\&Company, http:// www.mckinsey.com/insights/business technology/making data analytics work (viewed Nov 2015)

McIlroy, " M. (2008). “OMD Wins Intel's \$300 Million Account,” Adage.com, http://adage.com/article/ agency-news/omd-wins-intel-s-300-million-account/126697/ (viewed Nov 2015).

Mingers, J . (2012). "Abduction: The Missing Link between Deduction and Induction. A Comment on Ormerod's 'Rational Inference: Deductive, Inductive and Probabilistic Thinking'." J ournal of the Operational Research Society 63: 860-861.

Mohr, L.B. (1982). Explaining organizational behavior, San Francisco: J ossey Bass

Murer, S., Bonati, B., and Furrer, F. J. (2011). Managed Evolution: A Strategy for Very Large Information Systems, Berlin: Springer.

Negash, S. (2004). "Business Intelligence," Communications of the AIS (13), pp. 177-195.

Newell, A., and Simon, H. A. (1972). Human problem solving. Englewood Cliffs, NJ : Prentice-Hall. 
Peteraf, M. A., \& Barney, J. B. (2003). Unraveling the resource-based tangle. Managerial and Decision Economics, 24(4), 309-323.

Popovič, A., Hackney, R., Coelho, P. S., \& Jaklič, J. (2012). Towards business intelligence systems success: Effects of maturity and culture on analytical decision making. Decision Support Systems, 54(1), 729-739.

Pretz, J.E., Naples, A.J., and Sternberg, R.J. (2003). "Recognizing, Defining, and Representing Problems", in Davidson J E and Sternberg RJ eds. The Psychology of Problem Solving, Cambridge University Press, 2003, pp.3-30

Purvis, R. L., Sambamurthy, V., and Zmud, R. W. (2001). "The Assimilation of Knowledge Platforms in Organizations: An Empirical Investigation," Organization Science (12:2), pp.117-135.

Ramamurthy, K. R., Sen, A., \& Sinha, A. P. (2008). An empirical investigation of the key determinants of data warehouse adoption. Decision Support Systems, 44(4), 817-841.

Ricardo, D. (1817). On the Principles of Political Economy and Taxation, London: J ohn Murray http:// www.econlib.org/library/Ricardo/ ricPCover.html

SAP (2014). SAP HANA is a completely re-imagined platform for real-time business, http:// www.saphana.com/ welcome (viewed August 2014)

Sabherwal, R. and Becerra-Fernandez, I. (2011). Business Intelligence, Practices Technologies and Management, NewJ ersey:Wiley.

Saraiya, P., North, C., Lam, V., and Duca, K.A. (2006). An Insight-Based Longitudinal Study of Visual Analytics. IEEE Transactions on Visualization and Computer Graphics (12, 6), pp.1511-1522.

Schooler, J. W., Fallshore, M. and Fiore, S. M. (1996). "Epilogue: Putting Insight into Perspective”, in Sternberg RJ and Davidson JE, eds. The Nature of Insight, MIT Press, 1996, pp.559-587.

Seddon, P. B., Calvert, C., and Yang, S. (2010). "A multiproject model of key factors affecting organizational benefits from enterprise systems," MIS Quarterly (32:2), pp.305-328.

Shah S., Horne A., and Capella J. (2012). "Good data won't guarantee good decisions", Harvard Business Review 90(4), 23- 25.

Shanks, G. and Bekmamedova, N. (2012a). "Integrating Business Analytics Systems with the Enterprise Environment: an Evolutionary Process Perspective," Proceedings DSS2012 - 16th IFIP WG8.3 International Conference on Decision Support Systems, Anávissos, Greece, J une.

Shanks, G. and Bekmamedova, N. (2012b). Achieving benefits with business analytics systems: An evolutionary process perspective. J ournal of Decision Systems, 21(3), 231-244.

Sharma, R. S., Reynolds, P. J., Scheepers, R. S., Seddon, P. B., and Shanks, G. (2010). "Business Analytics and Competitive Advantage: A Review and Research Agenda," in Bridging the Sociotechnical Gap in Decision Support Systems - Challenges for the Next Decade. Amsterdam, Netherlands: IOS Press, pp. 187-198.

Simon, H. A. (1955). A behavioral model of rational choice. The Quarterly Journal of Economics, 69(1), 99-118.

Sternberg R. J . and Davidson J . E. (1996). The Nature of Insight, Cambridge MA: The MIT Press

Teece, D. J. 2009. Dynamic Capabilities and Strategic Management, Organizing for Innovation and Growth, Oxford: Oxford University Press.

Teece, D. J., Pisano, G., and Shuen, A. (1997). "Dynamic Capabilities and Strategic Management," Strategic Management J ournal (18:7), pp. 509-533.

Trkman, P., McCormack, K., De Oliveira, M. P. V., \& Ladeira, M. B. (2010). The impact of business analytics on supply chain performance. Decision Support Systems, 49(3), 318-327.

Vesset, D., and McDonough, B. (2009). "Improving Organizational Performance Management Through Pervasive Business Intelligence." IDC White paper \#217286.

Walsham, G. 2006. "Doing interpretive research," European J ournal of Information Systems (15:3), pp. 320-330.

Watson, H. J., and Wixom, B. H. (2007). "The Current State of Business Intelligence," Computer (40:9), pp. 96-99.

Webster, J., and Watson, R. T. (2002). "Analyzing the Past to Prepare for the Future: Writing a Literature Review," MIS Quarterly (26:2), pp. xiii-xxiii.

Wixom, B. H., and Watson, H. J. (2001). "An empirical investigation of the factors affecting data warehousing success," MIS Quarterly (25:1), pp. 17-41.

Wolfswinkel, J . F., Furtmueller, E., \& Wilderom, C. P. (2013). Using grounded theory as a method for 
rigorously reviewing literature. European J ournal of Information Systems, 22(1), 45-55.

Yogev, N., Fink, L., and Even, A. (2012). "How Business Intelligence Creates Value" ECIS 2012 Proceedings. Paper 84. http:// aisel.aisnet.org/ ecis2012/84 (viewed Nov 2015).

Zmud, R. (1995) Editor's Comments, MIS Quarterly (19:3), pp.xxxvii-xxxix.

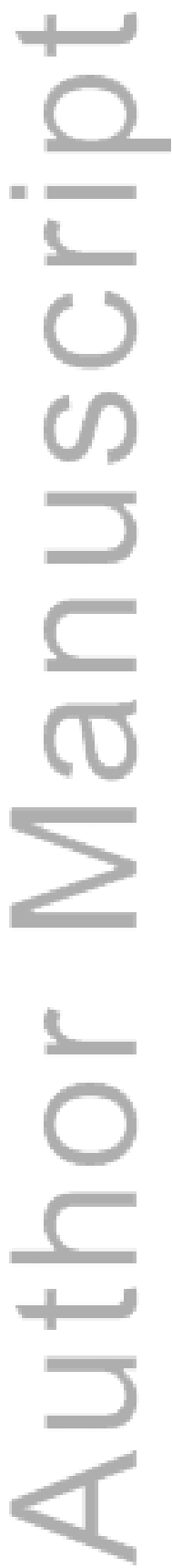

This article is protected by copyright. All rights reserved. 


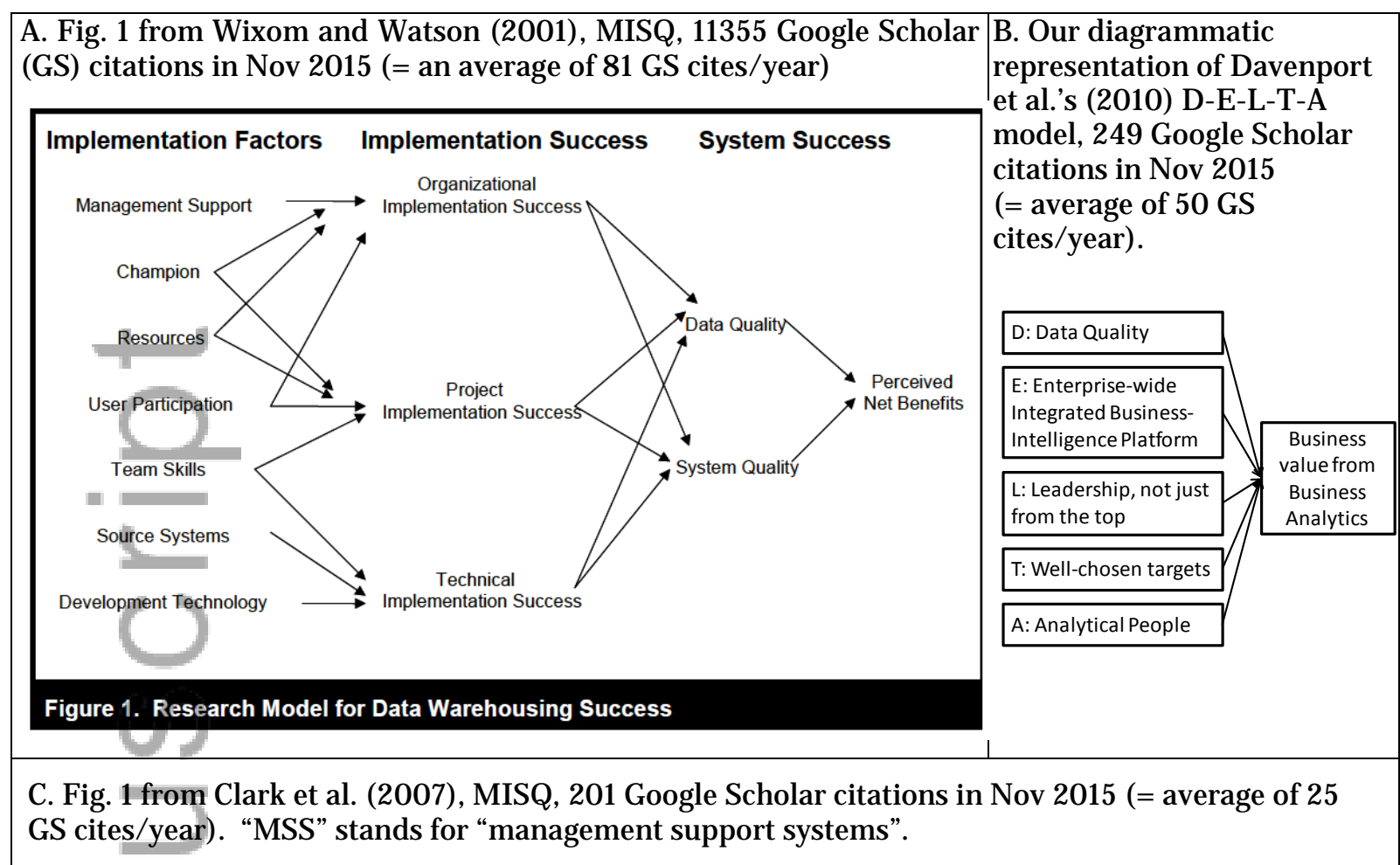

This article is protected by copyright. All rights reserved. 


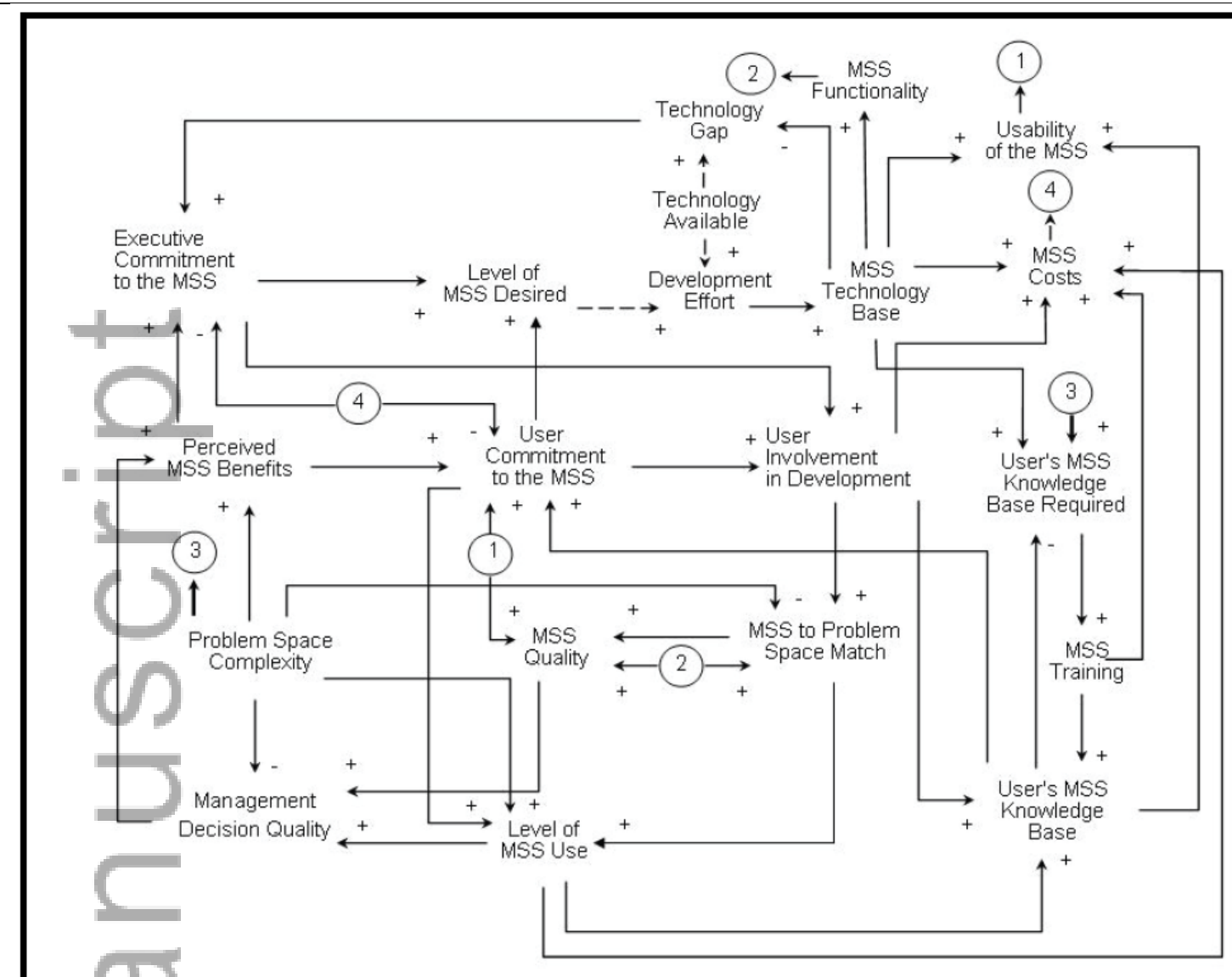

Figure 1. Dynamic Structure of MSS

Figure 1: Three highly cited models of factors leading to business value from analytics

This article is protected by copyright. All rights reserved. 


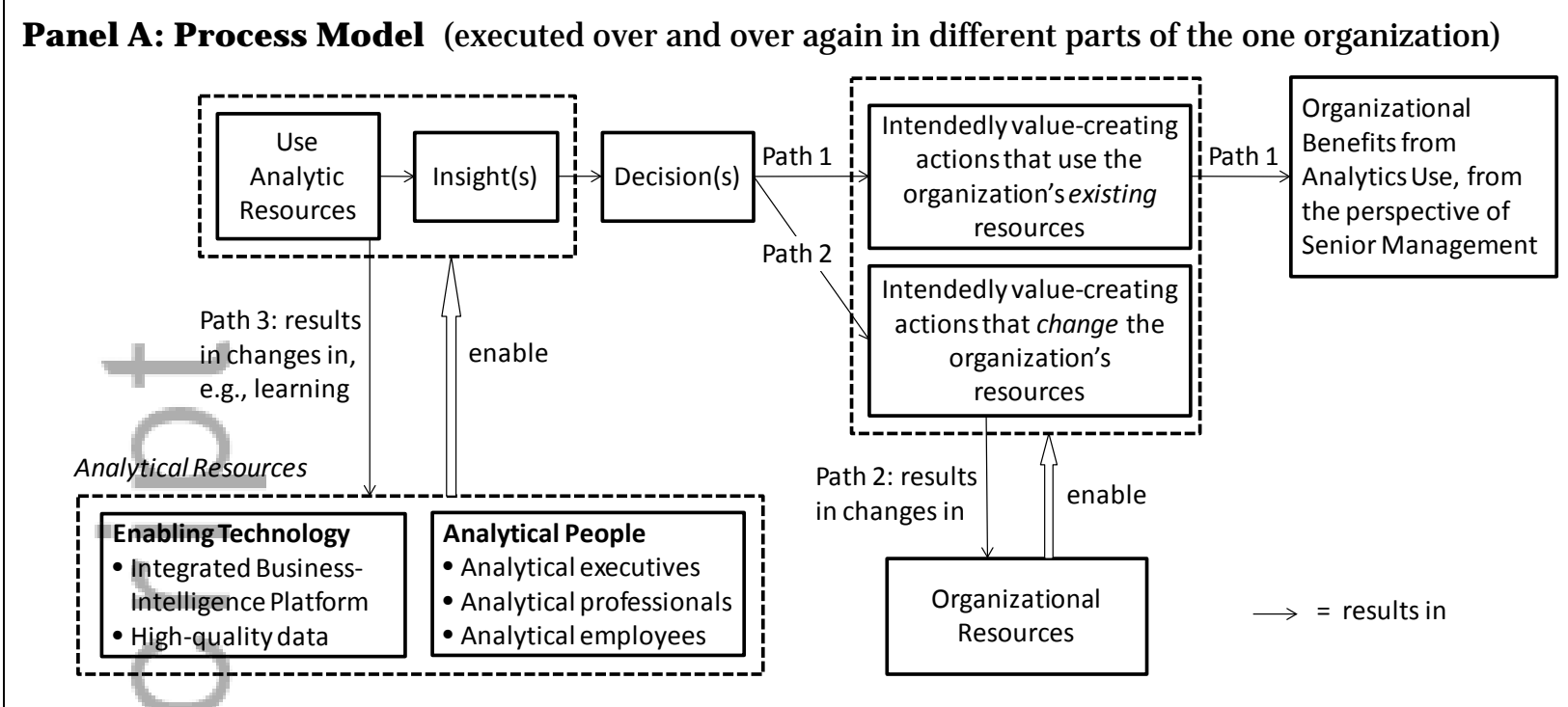

\section{Panel B: Variance model}

Long-term organizational benefits model

Short-term model: Factors driving benefits from each project

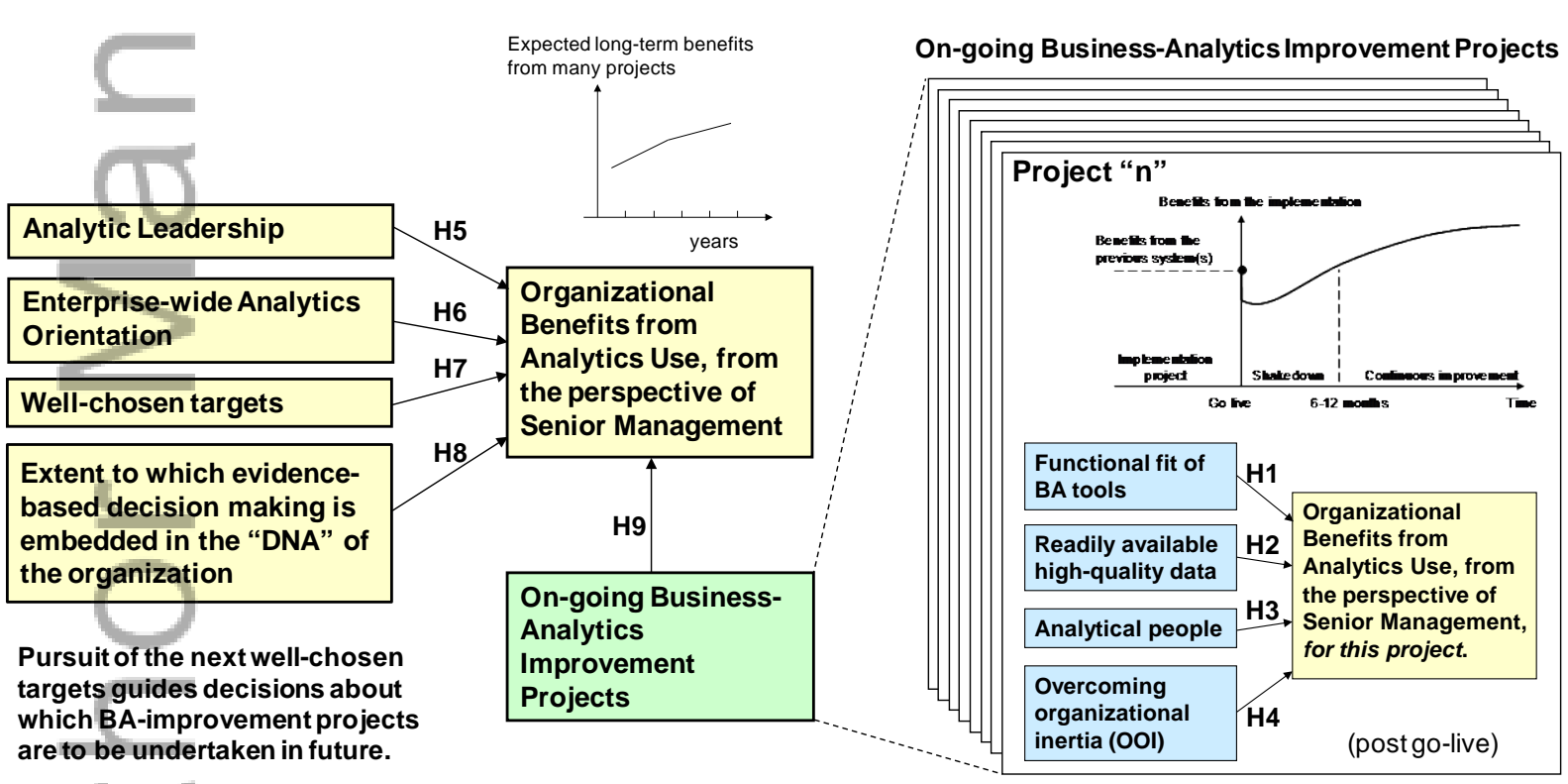

Figure 2: Proposed Business-Analytics Success Model (BASM)




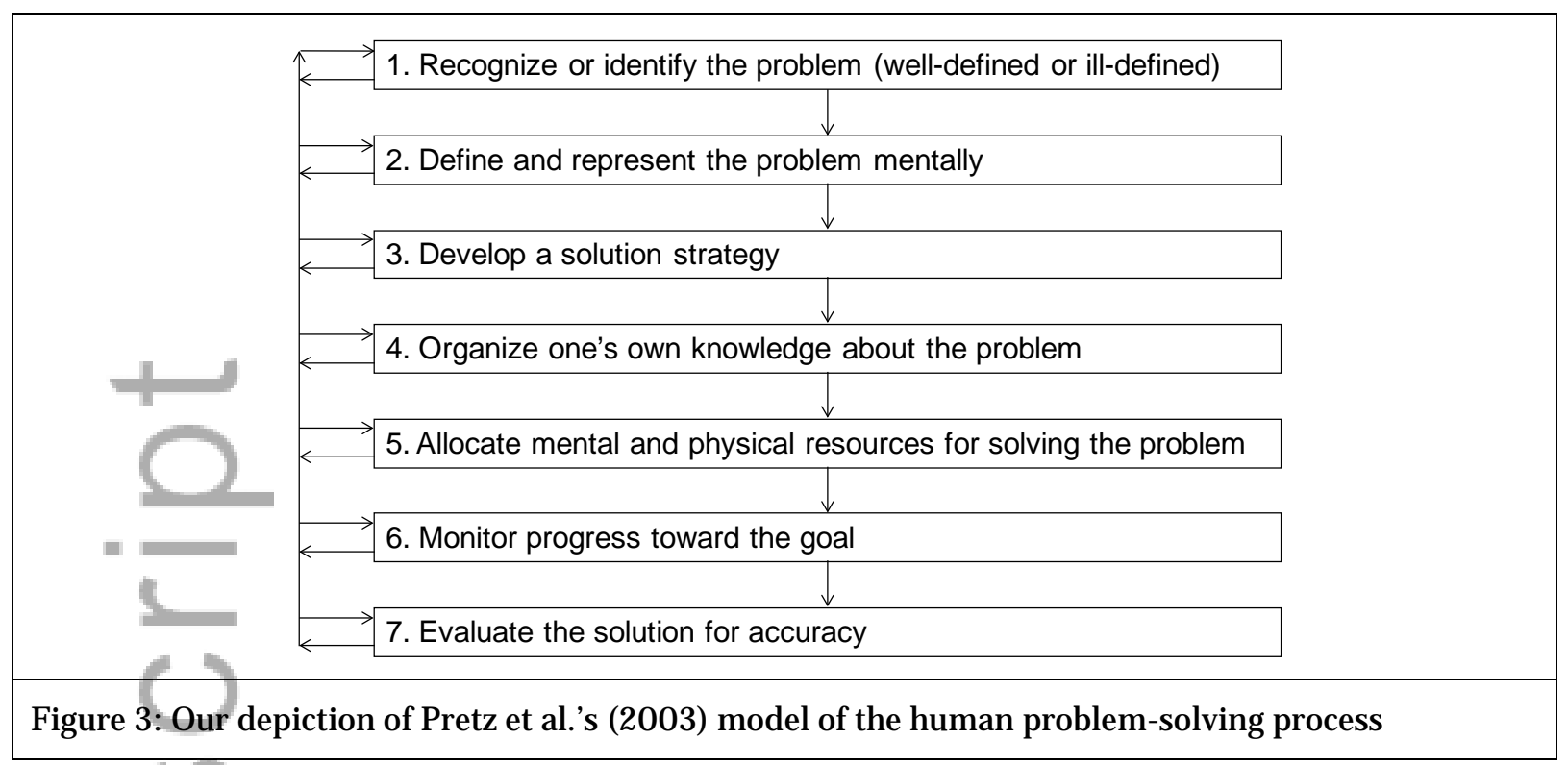

Figure 3: Our depiction of Pretz et al.'s (2003) model of the human problem-solving process

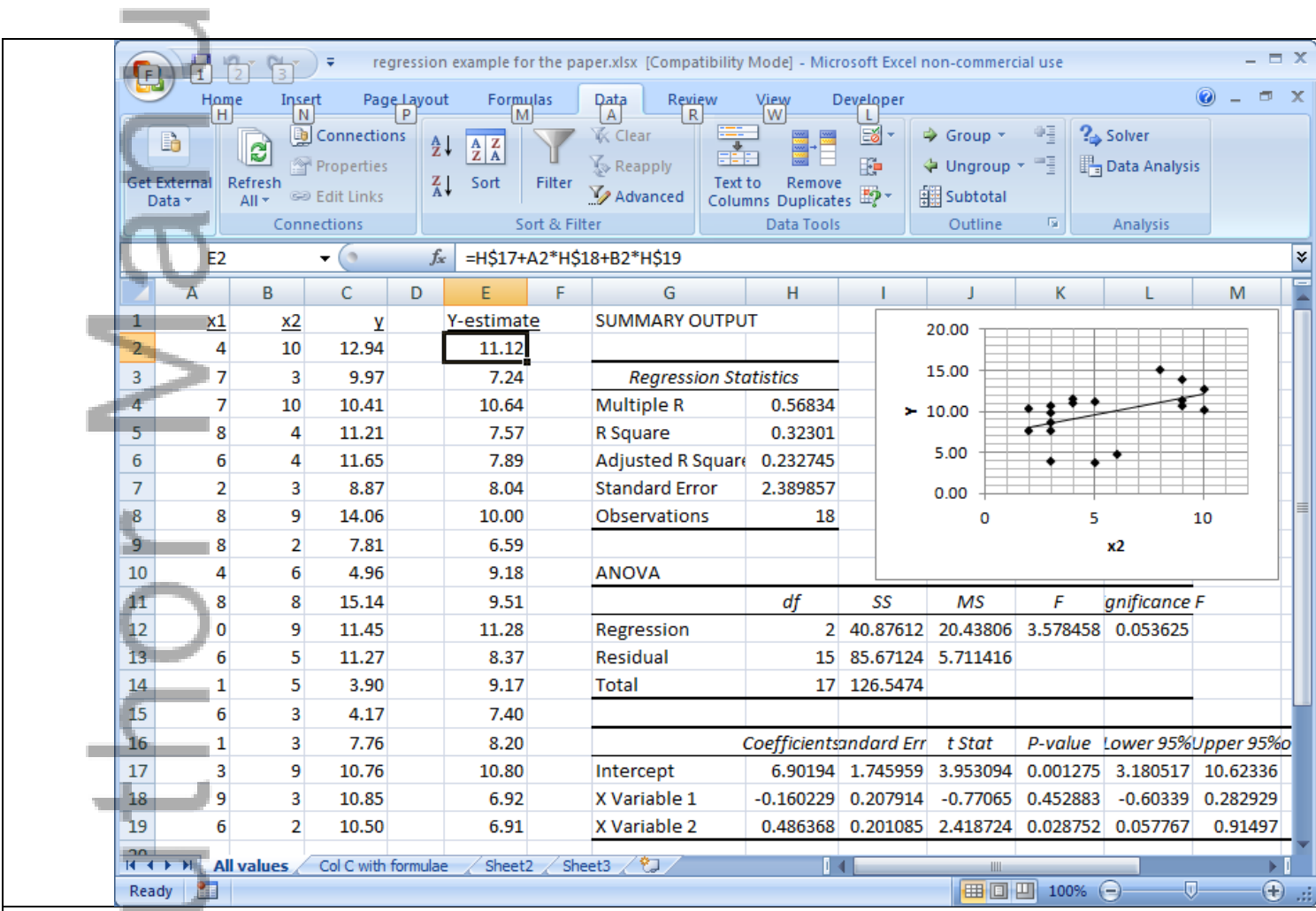

Figure 4: An example to illustrate human problem solving when using a simple business-analytics tool 


\section{Sharp HealthCare gets ahead of the curve: Performance management with IBM Cognos software}

Sharp HealthCare is a not-for-profit integrated regional health care delivery system based in San Diego, California that is comprised of four acute care hospitals, three specialty hospitals, two medical groups, a health plan and a full spectrum of other facilities and services. Sharp's 2,600 physicians and over 14,000 employees have an unwavering commitment to excellence and a passion for caring.

\section{Challenge}

Manual, error-prone processes and disparate, unreliable data drove Sharp to adopt a performance management system that could leverage their large data stores.

\section{Why IBM?}

Sharp chose IBM Cognos software for its business intelligence (BI) and analytics engine to leverage its data and enable faster decision-making while empowering departmental users through self-service capabilities.

\section{Solution}

IBM Cognos software is deployed as Sharp's standardized, single point of entry into their central data stores. BI is delivered to users through an easy to use, web-based, zero footprint solution that provides information faster, and in a more efficient and organized manner.

\section{Key Benefits}

Departmental users have direct access to the data they need to manage operations, understand trends and stay on top of workloads, and quality initiatives are supported with consistent and accurate data that helps Sharp measure results and improve operations.

Figure 5: Extract from page 1 of IBM's seven-page "Case Study" of Sharp Healthcare Source: http:// public.dhe.ibm.com/ common/ssi/ecm/en/imc14503caen/IMC14503CAEN.PDF 




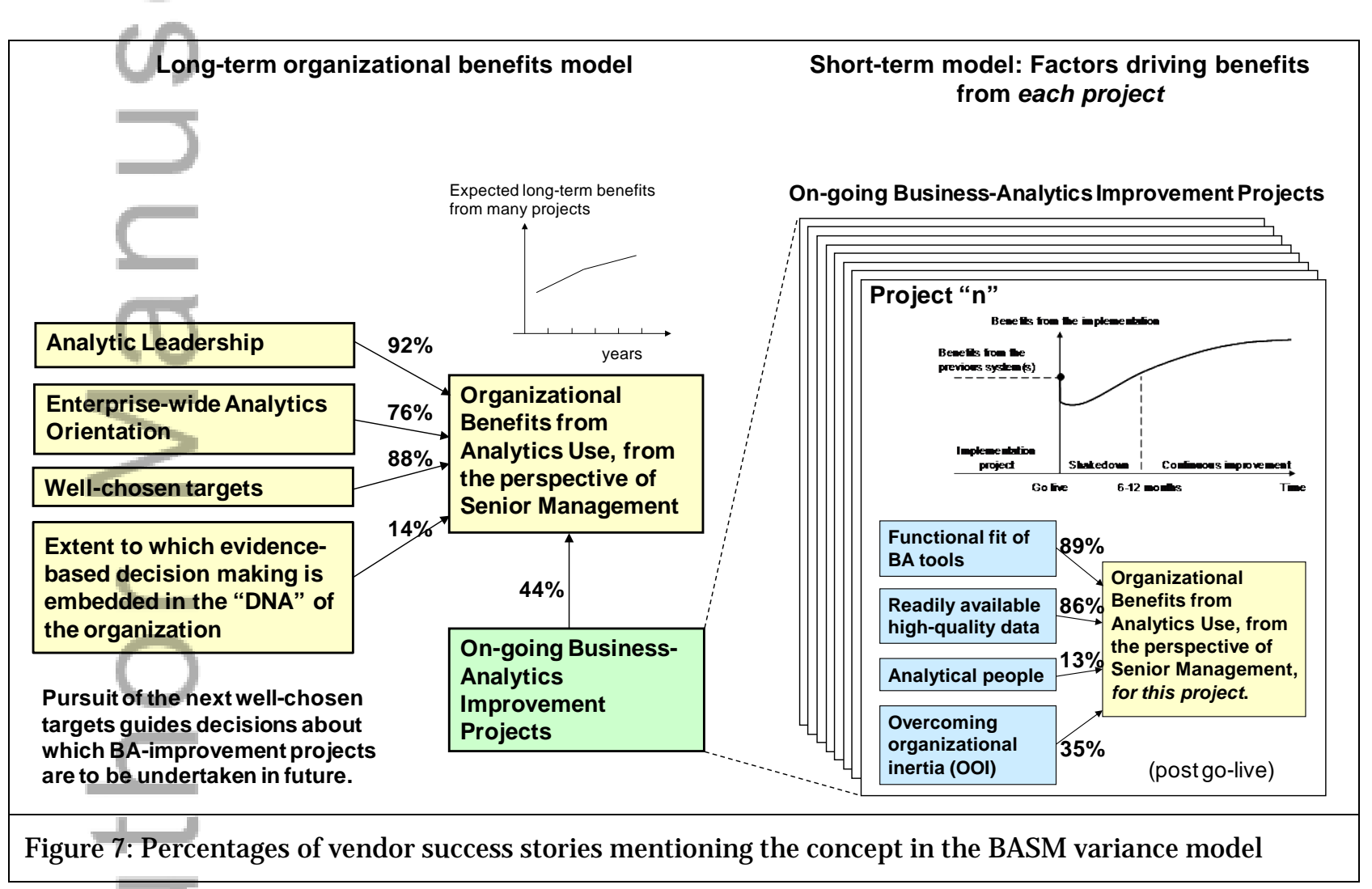


Table 1. Definition of concepts in the BASM Process Model (Figure 2, Panel A)

\begin{tabular}{|c|c|}
\hline Concept* $^{*}$ & Definition \\
\hline $\begin{array}{l}\text { 1. Use Analytic } \\
\text { Capabilities }\end{array}$ & $\begin{array}{l}\text { Use of business-analytic capabilities by any person or organizational unit to } \\
\text { analyze routine and/ or non-routine, internal and/ or external data to } \\
\text { support more evidence-based decision making. Howson (2011) classifies } \\
\text { BA usage types as: query, report, analyze, visualize, and alert, and points } \\
\text { out that people in different roles use BA in different ways. }\end{array}$ \\
\hline 2. Insight(s) & $\begin{array}{l}\text { The gaining of a deep or deeper understanding of something, arising from } \\
\text { use of business-analytic (BA) capabilities. Some insights are more valuable, } \\
\text { or more profound, than others. In the simplest of cases, insight may arise } \\
\text { simply as a result of reading a new report or viewing a dashboard. } \\
\text { Sometimes there is a flash of insight: "When the solution is seen, all the } \\
\text { parts suddenly seem to fit together" (Schooler et al. 1996, p.579). }\end{array}$ \\
\hline 3. Decision(s) & Decisions flowing from insights flowing from use of BA capabilities. \\
\hline $\begin{array}{l}\text { 4. Intendedly value- } \\
\text { creating actions that } \\
\text { use the organization's } \\
\text { existing capabilities }\end{array}$ & $\begin{array}{l}\text { Actions taken by the organization with a view to creating business value } \\
\text { that use its existing organizational capabilities (defined in row 10). Shanks } \\
\text { and Bekmamedova (2012a) call this concept Operational use of BA } \\
\text { capabilities. }\end{array}$ \\
\hline $\begin{array}{l}\text { 5. Intendedly value- } \\
\text { creating actions to } \\
\text { change the } \\
\text { organization's } \\
\text { capabilities } \\
\end{array}$ & $\begin{array}{l}\text { Actions taken by the organization with a view to creating business value } \\
\text { that lead to changes in its organizational capabilities (defined in row 10). } \\
\text { The capability to perform such actions, which includes the IT department's } \\
\text { capability to run IT-based projects successfully, is a dynamic capability } \\
\text { (Teece et al. 1997; Helfat et al. 2007). }\end{array}$ \\
\hline $\begin{array}{l}\text { 6. Organizational } \\
\text { Benefits from } \\
\text { Analytics Use }\end{array}$ & see Table 2, row 20, for the definition of this concept \\
\hline 7. Enabling Technology & $\begin{array}{l}\text { The hardware, software, data, processes (e.g., extract, transform and load } \\
\text { processes), and governance capabilities that make up the organization's } \\
\text { business-intelligence platform(s). (Davenport and Harris, 2007, Ch.8) }\end{array}$ \\
\hline 8. Analytical People & see Table 2, row 18, for the definition of this concept \\
\hline 9. Analytical Resources & $\begin{array}{l}\text { The organization's combination of people, technology, and data-analysis } \\
\text { processes that enable it to make more evidence-based decisions. These are } \\
\text { a very small subset of the organization's overall resources (row 10). In the } \\
\text { empirical analysis reported later, this construct was operationalized as the } \\
\text { union of scores for concepts in rows } 7 \text { and } 8 \text {. }\end{array}$ \\
\hline $\begin{array}{l}\text { 10. Organizational } \\
\text { Resources }\end{array}$ & $\begin{array}{l}\text { The full set of resources, i.e., people, technology, and processes, owned or } \\
\text { controlled by the organization that enable it to provide goods and services } \\
\text { (i.e., value) to its customers and other stakeholders. Some of these } \\
\text { resources will be the valuable, rare, inimitable, and non-substitutable } \\
\text { resources that the resource-based view of the firm (Barney 1991, Barney et } \\
\text { al. 2011) argues are the primary source of a firm's competitive advantage. }\end{array}$ \\
\hline
\end{tabular}

* Numbered rows correspond to row numbers in Table 4 
Table 2. Definition of concepts in the BASM Variance Model (Figure 2, Panel B)

\begin{tabular}{|c|c|}
\hline Concept* & Definition \\
\hline $\begin{array}{l}\text { 11. Analytic } \\
\text { Leadership }\end{array}$ & $\begin{array}{l}\text { The extent to which people in any organizational unit take leadership of } \\
\text { initiatives or projects to increase use of business analytics for organizational } \\
\text { gain (Davenport et al. 2010, Ch.4, pp.57-72). }\end{array}$ \\
\hline $\begin{array}{l}\text { 12. Enterprise-wide } \\
\text { Analytics } \\
\text { Orientation }\end{array}$ & $\begin{array}{l}\text { The extent to which the organization has adopted an enterprise-wide } \\
\text { orientation to the use of business analytics. Such an enterprise-wide view is } \\
\text { normally supported by an integrated BI platform that provides "a single, } \\
\text { holistic view of the company" (Davenport et al. 2010, p.45) rather than, for } \\
\text { example, multiple datamarts. }\end{array}$ \\
\hline $\begin{array}{l}\text { 13. Well-chosen } \\
\text { targets }\end{array}$ & $\begin{array}{l}\text { The extent to which targets for new analytics initiatives are selected carefully } \\
\text { based on the combination of their business potential and whether the } \\
\text { necessary resources, including data, are available (Davenport et al. 2010, } \\
\text { Ch.5). }\end{array}$ \\
\hline $\begin{array}{l}\text { 14. Extent to which } \\
\text { evidence-based } \\
\text { decision making } \\
\text { is embedded in } \\
\text { the "DNA" of the } \\
\text { organization }\end{array}$ & $\begin{array}{l}\text { The extent to which a culture of evidence-based decision making is } \\
\text { embedded in the core values and processes of the organization (Davenport } \\
\text { and Harris 2007, Ch.2; Davenport et al. 2010, Ch.1, 7, and 8). Kettinger et } \\
\text { al. (2011) describe this concept as the firm's Information Orientation. } \\
\text { Howson (2008) and IDC (Vesset and McDonaugh 2009) call it "pervasive } \\
\text { BI". Brynjolfsson calls it a "higher information metabolism" (Hopkins } \\
\text { 2010). }\end{array}$ \\
\hline $\begin{array}{l}\text { 15. On-going } \\
\text { Business- } \\
\text { Analytics } \\
\text { improvement } \\
\text { projects }\end{array}$ & $\begin{array}{l}\text { A measure of the number and extent of investment in BA-improvement } \\
\text { projects. Such projects include both the implementation of new software } \\
\text { (that delivers new analytics functionality) and initiatives that apply existing } \\
\text { functionality to new areas of decision making. These projects are } \\
\text { represented by the series of BA-Improvement Projects depicted on the right } \\
\text { of Panel B in Figure } 2 \text {. }\end{array}$ \\
\hline $\begin{array}{l}\text { 16. Functional fit of } \\
\text { BA tools (FF) }\end{array}$ & $\begin{array}{l}\text { The extent to which the functionality provided by the BI platform matches } \\
\text { the functionality that the organization needs to access and analyze data } \\
\text { effectively and efficiently. Saying that BA toolset has good functional fit is } \\
\text { equivalent to saying that the BA toolset helps people in the organization gain } \\
\text { useful insights from the organization's data. This includes providing fast } \\
\text { access to information when sought. Although FF is a meaningful concept for } \\
\text { the organization overall, in the BASM it is conceptualized as being delivered } \\
\text { and measured project by project (Seddon et al. 2010). }\end{array}$ \\
\hline $\begin{array}{l}\text { 17. Readily available } \\
\text { high-quality data }\end{array}$ & $\begin{array}{l}\text { The extent to which relevant and accurate data are readily available for } \\
\text { analytics use, from sources both within and external to the organization. } \\
\text { (Davenport et al. 2010, Ch.2, pp.23-43) }\end{array}$ \\
\hline 18. Analytical people & $\begin{array}{l}\text { The extent to which there are people within the organizational unit with an } \\
\text { analytic mindset who help drive business value from BA. (Davenport et al. } \\
\text { 2010) }\end{array}$ \\
\hline $\begin{array}{l}\text { 19. Overcoming } \\
\text { organizational } \\
\text { inertia (OOI) }\end{array}$ & $\begin{array}{l}\text { The extent to which members of the organization have been motivated to } \\
\text { learn, use, and accept the new system. During initial implementation and } \\
\text { subsequent projects, considerable change-management effort, training, and } \\
\text { support are needed to overcome organizational inertia. OOI is } \\
\text { conceptualized as being measured project by project (Seddon et al. 2010). }\end{array}$ \\
\hline $\begin{array}{l}\text { 20. Organizational } \\
\text { Benefits from } \\
\text { Analytics Use, } \\
\text { from the }\end{array}$ & $\begin{array}{l}\text { An overall measure of senior management's perception of the benefits from } \\
\text { analytics use. Such benefits-which may be assessed either for the use of BA } \\
\text { overall, or for individual BA projects-usually revolve around the use of } \\
\text { analytics to enable greater visibility into organizational data, resulting in }\end{array}$ \\
\hline
\end{tabular}




\begin{tabular}{|l|l|}
\hline $\begin{array}{l}\text { perspective of } \\
\text { Senior } \\
\text { Management }\end{array}$ & $\begin{array}{l}\text { better, more evidence-based, decision making. In almost all cases, such } \\
\text { benefits vary over time, e.g., as depicted in the two graphs in Figure 2. This } \\
\text { concept, which is directly analogous to the Organizational Benefits } \\
\text { dependent variable in Seddon et al. (2010), is a synonym for Business Value } \\
\text { from Business Analytics. }\end{array}$ \\
\hline
\end{tabular}

* Numbered rows correspond to row numbers in Table 4

Table 3: Examples of text from the Sharp Healthcare success story that was treated as providing evidence that the construct was a driver of organizational benefits

\begin{tabular}{|c|c|}
\hline Cor & text from the success story 1 \\
\hline $\begin{array}{l}\text { Organizational } \\
\text { Benefits, from the } \\
\text { perspective of } \\
\text { senior } \\
\text { management }\end{array}$ & $\begin{array}{l}\text { Sharp utilized IBM Cognos BI reporting capabilities to dramatically improve the } \\
\text { productivity of billers and claim processors by automating its claims management } \\
\text { inventory. (p.4) } \\
\text { "I hear consistent feedback from users that they are able to access information to } \\
\text { improve productivity." (DSS Manager, Brown, p.2) } \\
\text { Sharp was named a recipient of the } 2007 \text { Malcolm Baldrige National Quality } \\
\text { Award. ... Sharp's Rees-Stealy Medical Group has been recognized by Integrated } \\
\text { Healthcare Association (IHA) for best overall performance on important health } \\
\text { care quality measures, including preventive care and chronic care management, } \\
\text { patient satisfaction and use of information technology to support safer care. (p.6, } \\
\text { emphasis added) }\end{array}$ \\
\hline $\begin{array}{l}\text { Analy } \\
\text { Leade }\end{array}$ & $\begin{array}{l}\text { "I think we are ahead of the curve in implementing performance management } \\
\text { because not many other healthcare organizations have had a data warehouse as } \\
\text { long as we've had." (DSS Manager, Brown, p.2) }\end{array}$ \\
\hline $\begin{array}{l}\text { Enterr } \\
\text { Analyt } \\
\text { Orient }\end{array}$ & $\begin{array}{l}\text { The data warehouse unites charge, expense, revenue and clinical information- } \\
\text { from clinic, medical group, hospital, lab, pharmacy, physician orders, vital signs, } \\
\text { allergies, immunizations, operating room, encounters and referral data-into one } \\
\text { place to make operational decisions easier and more effective. (p.2) } \\
\text { It took the organization almost two years to make the transition from multiple } \\
\text { toolsets to an enterprise standard for reporting. (pp.3-4) }\end{array}$ \\
\hline $\begin{array}{l}\text { Ongo } \\
\text { (H9) }\end{array}$ & $\begin{array}{l}\text { "We capture information on about } 17 \text { different quality indicators, and are } \\
\text { developing a dashboard and custom report that will let physicians see where they } \\
\text { stand against each of these indicators on a monthly basis" (DSS Manager, Brown, } \\
\text { p.6) } \\
\text { Sharp is in the process of deploying its new clinical information system to support } \\
\text { electronic medical records. (p.7) }\end{array}$ \\
\hline $\begin{array}{l}\text { Function } \\
\text { (H1) }\end{array}$ & $\begin{array}{l}\text { "For the most part, my IT team does not build reports," she said. "We have done a } \\
\text { few that go across multiple medical groups or multiple entities, but for the most } \\
\text { part, we build the infrastructure-the data models-and allow our users to just go } \\
\text { ahead and access the BI and performance information they need." (Brown p.4) } \\
\text { In addition, IBM Cognos BI software delivers graphical Excel integration } \\
\text { capabilities, which according to Brown, "have been very helpful for convincing } \\
\text { die-hard spreadsheet users to switch over!"(p.4) }\end{array}$ \\
\hline $\begin{array}{l}\text { Ready availability } \\
\text { of high-quality } \\
\text { data (H2) }\end{array}$ & $\begin{array}{l}\text { "I am now } 100 \text { percent confident in the data that we have so that users can count } \\
\text { on the reliability of their reports" (DSS Manager, Brown, p.2) }\end{array}$ \\
\hline $\begin{array}{l}\text { Overcoming } \\
\text { Organizational }\end{array}$ & t many users did their jobs. We were \\
\hline
\end{tabular}




\begin{tabular}{|l|l|}
\hline $\begin{array}{l}\text { afraid that users would not respond well to change" (DSS Manager, Brown, p.4) } \\
\text { "Moving over to performance management entails a huge learning curve for any } \\
\text { organization," said Carol Wanke. “Change management is significant, and the } \\
\text { support must be there." (Director, Patient Financial Services, Wanke, p.5) }\end{array}$ \\
\hline
\end{tabular}

Success story: http://public.dhe.ibm.com/common/ssi/ecm/en/imc14503caen/IMC14503CAEN.PDF (viewed Aug 2014) reproduced on http:// locussolutions.com/ wp-content/ uploads/2015/ 03/ Casestudy-Sharp-Healthcare.pdf (viewed Nov 2015).

${ }^{1}$ The words in the right column above are exact quotations from the 8-page success story. Words in quotation marks were in quotation marks in the success story.

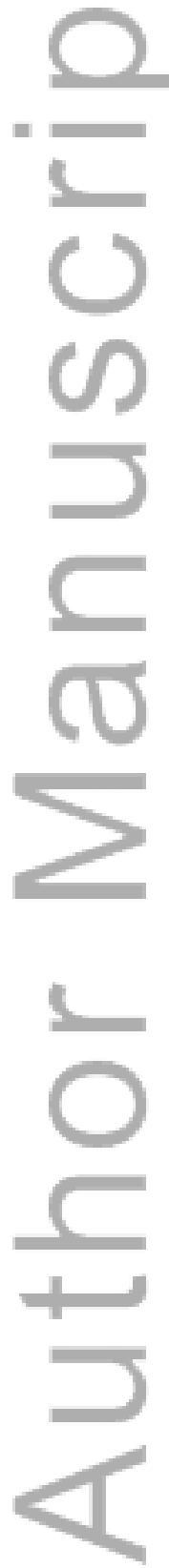

This article is protected by copyright. All rights reserved. 
Table 4: Results from analysis of 100 customer-success stories

\begin{tabular}{|c|c|}
\hline Concept from the Business-Analytics Success Model (BASM)\# & $\begin{array}{l}\text { \% of stories } \\
\text { mentioning* }\end{array}$ \\
\hline \multicolumn{2}{|l|}{ Process Model (Panel A, Figure 2): } \\
\hline $\begin{array}{l}\text { 1. Use of business analytic resources by any organizational unit to analyze routine } \\
\text { and/ or non-routine, internal and/ or external data }\end{array}$ & $98 \%$ \\
\hline 2. Insight(s) (arising from use of business analytic resources) & $89 \%$ \\
\hline 3. Decision(s) (flowing from insights flowing from use of BA resources) & $81 \%$ \\
\hline 4. BA-driven Competitive actions that use existing organizational resources & $88 \%$ \\
\hline 5. BA-driven Competitive actions to change organizational resources & $6 \%$ \\
\hline $\begin{array}{l}\text { 6. " Organizational Benefits from Analytics Use, from the perspective of Senior } \\
\text { Management }\end{array}$ & $98 \%$ \\
\hline 7. Enabling technology & $100 \%$ \\
\hline 8. Analytical people & $12 \%$ \\
\hline 9. Analytical resources (union of the sets of codes for rows 7 and 8) & see row 7 \\
\hline 10. Organizational resources (being used in the creation of business value) & $100 \%$ \\
\hline \multicolumn{2}{|l|}{ Variance Model (Panel B, Figure 2): } \\
\hline 11. H5: Analytic leadership (as a long-term driver of organizational benefits) & $92 \%$ \\
\hline 12. H6: Enterprise-wide Analytics Orientation (as a driver of org. benefits) & $76 \%$ \\
\hline 13. H7: Well-chosen targets (for new BA initiatives) (as a driver of org. benefits) & $88 \%$ \\
\hline $\begin{array}{l}\text { 14. H8: Extent to which evidence-based decision making is embedded in the "DNA" } \\
\text { of the organization (as a driver of org. benefits) }\end{array}$ & $14 \%$ \\
\hline 15. H9: On-going BA-improvement projects (as a driver of org. benefits) & $44 \%$ \\
\hline 16. H1: Functional fit (of the BI tools to meet the needs of users for this project) & $89 \%$ \\
\hline $\begin{array}{l}\text { 17. H2: Readily available high-quality data (as a driver of org. benefits, for this } \\
\text { project) }\end{array}$ & $86 \%$ \\
\hline 18. H3: Analytical people (as a driver of org. benefits for this project) & $13 \%$ \\
\hline 19. H4: Overcoming organizational inertia (as a driver of org. benefits for this proj.) & $35 \%$ \\
\hline 20. Organizational Benefits from Analytics Use & see row 6 \\
\hline
\end{tabular}

* Percentages are of the 100 vendors' customer-success stories analyzed.

\# Numbered rows correspond to row numbers in Tables 1 and 2.

This article is protected by copyright. All rights reserved. 


\section{HOW DOES BUSINESS ANALYTICS CONTRIBUTE TO BUSINESS VALUE?}

Suggested running headline: How does analytics contribute business value?

Peter B. Seddon
Department of Computing and Information Systems
The University of Melbourne, Victoria, Australia
p.seddon@unimelb.edu.au
Dora Constantinidis
$\begin{gathered}\text { Department of Computing and Information Systems } \\ \text { The University of Melbourne, Victoria, Australia } \\ \text { dorac@unimelb.edu.au }\end{gathered}$
Toomas Tamm
$\begin{gathered}\text { Department of Computing and Information Systems } \\ \text { The University of Melbourne, Victoria, Australia } \\ \text { toomas.tamm@unimelb.edu.au }\end{gathered}$
Harjot Dod
Department of Computing and Information Systems
The University of Melbourne, Victoria, Australia
harjot4u@gmail.com

Paper length: 11,600 words

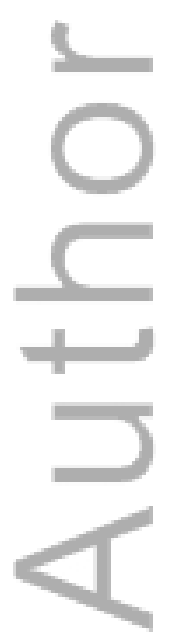




\section{University Library}

\section{- M M I N E R VA A gateway to Melbourne's research publications}

Minerva Access is the Institutional Repository of The University of Melbourne

Author/s:

Seddon, PB;Constantinidis, D;Tamm, T;Dod, H

Title:

How does business analytics contribute to business value?

Date:

2017-05-01

Citation:

Seddon, P. B., Constantinidis, D., Tamm, T. \& Dod, H. (2017). How does business analytics contribute to business value? INFORMATION SYSTEMS JOURNAL, 27 (3), pp.237-269. https://doi.org/10.1111/isj.12101.

Persistent Link:

http://hdl.handle.net/11343/291169 